
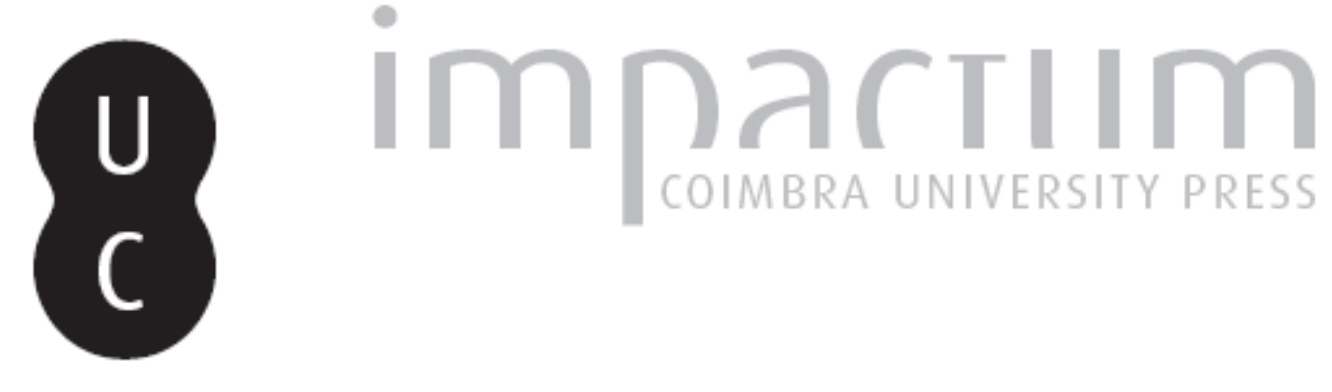

\title{
Os Diálogos de Doutrina Democrática: da edição original (1933) à versão revista pelo autor (1945/1958?)
}

\section{Autor(es): $\quad$ Matos, Sérgio Campos}

Publicado por: Imprensa da Universidade de Coimbra

URL persistente:

URI:http://hdl.handle.net/10316.2/45054

DOI:

DOI:https://doi.org/10.14195/2183-8925_5-1_15

Accessed : $\quad$ 26-Apr-2023 12:52:18

A navegação consulta e descarregamento dos títulos inseridos nas Bibliotecas Digitais UC Digitalis, UC Pombalina e UC Impactum, pressupõem a aceitação plena e sem reservas dos Termos e Condições de Uso destas Bibliotecas Digitais, disponíveis em https://digitalis.uc.pt/pt-pt/termos.

Conforme exposto nos referidos Termos e Condições de Uso, o descarregamento de títulos de acesso restrito requer uma licença válida de autorização devendo o utilizador aceder ao(s) documento(s) a partir de um endereço de IP da instituição detentora da supramencionada licença.

Ao utilizador é apenas permitido o descarregamento para uso pessoal, pelo que o emprego do(s) título(s) descarregado(s) para outro fim, designadamente comercial, carece de autorização do respetivo autor ou editor da obra.

Na medida em que todas as obras da UC Digitalis se encontram protegidas pelo Código do Direito de Autor e Direitos Conexos e demais legislação aplicável, toda a cópia, parcial ou total, deste documento, nos casos em que é legalmente admitida, deverá conter ou fazer-se acompanhar por este aviso.

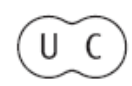




\section{REVISTA DE HISTÓRIA DAS IDEIAS 5}

\section{António Sérgio}

*

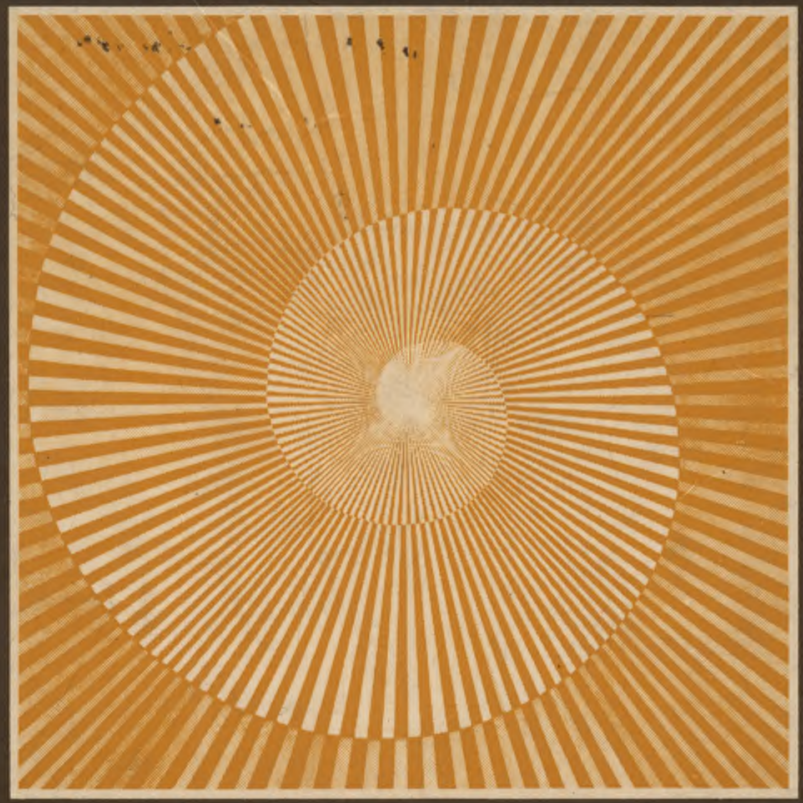

INSTITUTO DE HISTÓRIA E TEORIA DAS IDEIAS FACULDADE DE LETRAS 


\section{OS DIÁLOGOS DE DOUTRINA DEMOCRÁTICA: da edição original (1933) à versão revista pelo autor (19457/1958?)}

«Bárbaro - é todo aquele que não clarifica as suas ideias, que não põe coerência no seu espírito, que não busca a ordem dentro de si (como V. Ex. ${ }^{a}$ ). Bárbaros autênticos são esses tais - para todos os homens europeus que têm espírito de europeu...

Há uma maneira ininteligente (como há uma maneira inteligente) de ser monárquico, republicano, socialista, etc.: $e$ o que eu peço todos os dias aos meus mais jovens compatriotas não é que abandonem as suas «ideias» (os seus credos, partidos, fés): é que busquem ser inteligentemente (civilizadamente, europeiamente) aquilo mesmo que dizem sern.

António Sérgio, «Explicações a um catedrático de Direito sobre a doutrina ética dos meus Ensaios», Ensaios VII, $\mathbf{l}^{\mathbf{a}}$ ed., Lisboa, Sá da Costa, 1974, p. 164.

\section{INTRODUÇÃO}

Decorridos mais de catorze anos sobre a morte de António Sérgio, e mais de vinte sobre a publicação dos seus últimos escritos, ainda hoje a sua imensa obra permanece desconhecida do grande público, e ignorada em certos meios universitários portugueses.

Desconhecida, por factores de ordem política e cultural: o obscurantismo salazarista e nos anos que se seguiram ao 25 de Abril de 1974, a ausência de uma política cultural clara, que acabasse com o analfabetismo, combatesse a igno-

* Professor do Ensino Básico. 
rância e contribuísse para a formação cívica de vastas camadas da população; e também por razões que se prendem com características do ensaísmo sergiano, com particularidades da sua linguagem, às quais não tem sido dada devida atenção.

Uma análise dos textos, feita do ponto de vista dos níveis de língua utilizados pelo autor, poderia ser bastante esclarecedora, no que respeita a este último aspecto.

Não procedemos a uma análise sistemática dos Diálogos nessa perspectiva, mas, de qualquer modo, o estudo das anotações manuscritas, introduzidas por Sérgio na versão original, já aponta para algumas conclusões significativas, que conviria cotejar com as anotações inseridas noutras obras.

Os objectivos do presente trabalho são essencialmente:

1. Fornecer aos interessados no pensamento de António Sérgio os resultados de uma análise que facilite a compreensão do texto.

2. Destacar as transformações (variantes, supressões e acrescentos de palavras, frases e textos) decorrentes da revisão da edição original, feita pelo autor.

3. Explorar o sentido das anotações, na tentativa de entrever que evolução se verifica no pensamento e na linguagem de Sérgio, num período muito fecundo da sua actividade (1933-1958).

De entre a impressionante vastidão de títulos da bibliografia sergiana, escolhemos os Diálogos de Doutrina Democr ática para este tipo de abordagem, por diversas razões:

1. Nos Diálogos, Sérgio aborda uma grande diversidade de temas, já aflorados por Salazar, nas entrevistas concedidas alguns meses antes a António Ferro.

2. O facto de ser uma obra de polémica, em que o ensaíasta defronta o seu mais poderoso adversário ideológico e político, sob a forma de um diálogo em que os dois interlocutores correspondem a personalidades reais, o que lhe confere, como é obvio, imenso interesse, sob diversos pontos de vista.

3. Finalmente, porque constituem um texto não muito extenso que foi revisto, pelo menos, em dois momentos diferentes, com intervalos de cerca de doze anos entre a versão original (1933) e a primeira revisão (1945?), e de cerca de treze anos, entre a primeira e a segunda revisões (1958?), adequando-se de modo particularmente eficaz aos objectivos que nos propusemos.

Um campo de análise que deliberadamente não aprofundámos, e que é uma constante ao longo das intervenções do Libertário (personagem que corresponde ao autor), é a des- 
montagem do discurso de Salazar, desmontagem ordenada, sistemática, tenaz, que não poupa as frequentes contradições em que o ditador cai no domínio da lógica; numa luta obstinada contra o ecletismo ideológico, obscuro e pouco definido; numa permanente procura da limpidez do pensamento, da clareza das ideias.

Seria também interessante verificar que temas abordados por Salazar nas suas entrevistas, não foram explorados por Sérgio nos Diálogos. Tal levantamento, levar-nos-ia por certo a conhecer mais profundamente as polémicas que Sérgio travou com o ditador em diversos textos de circunstância: nos «Retalhos de Doutrina Democrática», da Seara Nova (Jan./Março de 1933) (mais tarde inclúi.dos nos Ensaios VII com o título Relanços de Doutrina Demoôrática), no $10 .^{\circ} \mathrm{Ca}$ derno da Antologia Sociológica (1956/1957) e no Pátio das Comédias (1958).

\section{PARA A COMPREENSÃO DA OBRA.}

\subsection{As condições de produção: das entrevistas a Salazar, à réplica de António Sérgio.}

Os seis Diálogos de Doutrina Democrática, cinco dos quais permaneceram inéditos até 1974, foram certamente escritos em 1933 0), tinha António Sérgio cerca de cinquenta anos.

Antecedendo o texto, uma advertência em sentido figurado, escrita por certo em 1958 informa o leitor:

«Esta obra foi escrita há mais de vinte anos. Ficou esquecida numa gaveta, e só agora me lembrei da sua existência e me ocorreu a ideia de a publicar» $\left({ }^{2}\right)$.

Mas em que circunstâncias é que Sérgio escreveu esta obra «maldita», que nas bibliografias publicadas em sua vida, vinha ambiguamente referenciada como «publicação suspensa»??

Os Diálogos constituem a réplica do ensaísta recém-chegado do exílio em França, às entrevistas que António Ferro

(D Tal é a sugestão de Augusto Abelaira e de Idalina Sá da Costa em Democracia, l. ${ }^{\mathrm{a}}$ ed., Lisboa, Sá da Costa, 1974 p. IX, e também de A. Campos Matos na Bibliografia de António Sérgio, de Vértice, Coimbra, 1971, p. 12.

O Democracia..., Lisboa, Sá da Costa, 1974, p. 1. 
fizera poucos meses antes ao recém-empossado presidente do conselho António de Oliveira Salazar $\left(^{3}\right)$.

Em cima do acontecimento, a 12 de Janeiro e a 2 de Março de 1933, Sérgio publica na Seara Nova dois artigos intitulados «Retalhos de Doutrina Democrática», em que respondendo já às entrevistas de Salazar, sintetiza os principais temas que há-de desenvolver nos Diálogos.

Nos finais de Abril aparece na Seara o «Diálogo de um democrata e de um estadista burguês» $\left({ }^{4}\right)$, texto que depois de ser revisto pelo autor veio a constituir o Diálogo Quinto, intitulado, «Da Sociedade Nova e do Estado Novo». Este artigo era certamente o primeiro de uma série que Sérgio tinha em mente publicar. Mas, não só seria o único Diálogo a vir à luz do dia, em vida do autor e durante a ditadura que se manteve até ao 25 de Abril, como o próprio livro intitulado Diálogos de Doutrina Democrática, que entretanto tentou publicar na editora da Seara Nova, foi apreendido pela censura quando ainda estava em vias de ser impresso, na Tipografia da Calçada do Tijolo, em 1933.

Da edição original, sem capa nem rosto, existem hoje, ao que sabemos, apenas três exemplares $\left(^{5}\right)$.

Foi-nos impossível, por falta de informações, precisar em que altura do ano de 1933 terá a edição original sido impressa.

Segundo Castelo Branco Chaves, os Diálogos foram já escritos em Lisboa, depois do regresso de Sérgio do exílio em Paris $\left({ }^{\mathrm{G}}\right)$. Sabemos que nos princípios de Março de 1933, ainda se encontrava em Santiago de Compostela, onde leccionou durante alguns meses um curso sobre História e Literatura Portuguesas, a convite da Universidade local $\left({ }^{7}\right)$, e que o já refe-

(3) As entrevistas a Salazar foram publicadas pela primeira vez no Diário de Notícias de 18 a 24 de Novembro de 1932 e depois reunidas em livro, Salazar o homem e a sua obra, em Fevereiro de 1933.

(4) Seara Nova, n. ${ }^{\circ} 340,27$ de Abril de 1933; ao que sabemos, trata-se da primeira exposição sistemática do programa cooperativista, em alternativa ao corporativismo, que é pormenorizadamente criticado; note-se ainda, que, neste diálogo, o Democrata trata o Estadista Burguês por você, forma que Sérgio viria a modificar, na versão dos Diálogos.

C) Destes três exemplares, um pertencia a António Sérgio, o um outro a Câmara Reys.

$\left(\begin{array}{l}6 \\ 7\end{array}\right)$ Informação amavelmente fornecida por este crítico.

(7) O artigo intitulado «Grupo 'Renovação Democrática'», publicado na Seara Nova a 30.3 .1933 foi escrito no dia 9 do mesmo mês, ainda em Santiago. Segundo informação de Jacinto Baptista, Sérgio esteve em Santiago de Janeiro a Maio de 1933, regressando então a Portugal, abrangido por uma amnistia. Viria no entanto a ser preso pouco tempo depois, por duas vezes. Da primeira, anterior a 18 
rido «Diálogo de um Democrata e de um Estadista Burguês», publicado em fins de Abril, foi minuciosamente revisto antes de ser integrado naquela obra, com o novo título «Da Sociedade Nova e do Estado Novo»».

Por outro lado, verificámos que há passagens de um artigo dos Ensaios III, publicados em 1932, e de um artigo da Seara Nova de fins de Maio de $1933\left({ }^{8}\right)$ que correspondem - se exceptuarmos pequenas modificações - a passagens dos Diálogos Terceiro e Sexto da obra de que nos ocupamos. Da comparação destes trechos com os que lhes são correspondentes nos Diálogos, apercebemo-nos que estes últimos só podem ter sido posteriores.

Chegamos então à conclusão, que a versão primitiva não foi concerteza escrita antes de Maio de 1933.

De qualquer modo, o problema da datação desta edição original, não é aqui de grande importância, uma vez que teve uma difusão muito limitada, provavelmente apenas entre os amigos íntimos do autor, por ter sido, como dissemos, apreendida pela censura quando ainda se encontrava no prelo.

Quanto às anotações manuscritas introduzidas por Sérgio posteriormente, a sua análise levou-nos a apontar os anos de 1945 e de 1958 como datas prováveis para a sua elaboração.

A edição crítica que consultámos, inserida no volume das Obras Completas, intitulado Democracia, foi impressa em Fevereiro de 1974 e baseia-se no texto do exemplar que pertencia ao espólio de António Sérgio, por ele profusamente anotado.

Os organizadores desta edição decidiram manter o título original, por ser o mais conhecido, embora Sérgio o tivesse modificado para Diálogos entre um Estadista e um Libertário, de acordo aliás, com a alteração dos nomes das personagens de «Democrata» e «Estadista Burguês» para «Libertário» e «Estadista».

Independentemente da dificuldade em datar com precisão o mês em que a primitiva edição foi impressa, o certo é

de Julho, esteve incomunicável durante 5 horas, findas as quais o soltaram» («Duas cartas de Luisa Sérgio a Bernardino Machado de 18 de Julho e de 19 de Dezembro de 1933», O Ponto, 15.6.1982); na segunda, esteve detido durante vários meses. Terão estas prisões alguma relação com a tentativa de publicação dos Diálogos, e com a sua suspensão pela censura?

$\left({ }^{8}\right)$

Trata-se de duas passagens sobre a reforma do ensino nas escolas rurais e nas escolas normais, incluídas no artigo «Reforma da Instrução popular», Ensaios III, pp. 259-263, e da definição de cooperativismo de "Cooperativa e Parlamento", Seara Nova, 25.5.1933; confrontem-se esses trechos com os dos Diálogos (p. 47; p. 78). 


\section{António Sérgio}

que ela foi produzida numa conjuntura económica de crise exacerbada no mundo ocidental, marcada ao nível político pela ascensão e reforço de regimes autoritários e fascistas na Europa $\left({ }^{9}\right)$, e pela instabilidade dos regimes de democracia parlamentar $\left({ }^{10}\right)$.

Em Portugal, desde Abril de 1928, um catedrático da Universidade de Coimbra, que mais tarde Sérgio qualificaria de «antidemocrata e maquiavélico» $\mathrm{O}^{1}$ ), detinha o posto chave no governo da ditadura militar: o Ministério das Finanças. A partir de 1930, e sobretudo de 1932, lançam-se os alicerces do estado corporativo. Em Julho deste último ano, o «maquiavélico» professor ascende a presidente do conselho de ministros e, em Fevereiro seguinte, é publicada a Constituição, que seria triunfalmente plebiscitada a 19 de Março.

Em Dezembro de 1932, como vimos, o ditador fazia-se entrevistar pelo jornalista António Ferro, e abordava questões tão controversas como então (ainda) eram a censura, a problemática da liberdade e da autoridade, as relações entre o fascismo e a ditadura, o problema da instrução, etc.

A crítica que, a dado passo, Salazar faz às reformas que os democratas se propunham introduzir no funcionamento do parlamento $\left({ }^{12}\right)$, visava sem dúvida o grupo dos seareiros

() Em Dezembro de 1932 instaura-se na Lituânia um Estado autoritário de partido único; em Janeiro de 1933 Hitler sobe ao poder e em Março do mesmo ano, Dollfus controla a situação na Áustria através de um golpe de Estado. Ainda nesse ano, Roossevelt lança a New Deal nos Estados Unidos para tentar ultrapassar a crise económica que se prolongava desde 1929 e funda-se a Falange espanhola. Em 1934, seria a vez da Estónia e da Letónia se submeterem a regimes ditatoriais.

Sérgio, profundo conhecedor da realidade politica europeia, afirmava confiante, nos Diálogos: «O que nós vimos até agora foi o crepúsculo aurorai da Democracia, obscurecido neste momento por uma nuvem negra que lá vai surgindo. O sol verdadeiro não apontou ainda.» Democracia, Lisboa, Sá da Costa, $1 .^{\mathrm{a}}$ ed., 1974, p. 74.

$\left.{ }^{10}\right)$ No início dos anos 30 sucedem-se em França frequentes mudanças de governo, enquanto em Inglaterra se constituem governos de coligação nacional, na tentativa de superar a crise económica.

(") Vide Ensaios VII, l. ${ }^{\text {a }}$ ed., 1974, p. 184.

(12) Sob o título da responsabilidade de António Ferro «A Crise da Democracia», Salazar invectivara mordazmente os democratas nestes termos: «Mas que propõem eles, afinal, para que se efective essa renovação? [dos órgãos da democracia] Medidas ridículas que não se adaptam ao próprio sistema: ligeiras alterações no regulamento interno das Câmaras, limitação no tempo dos discursos, restrições no uso da palavra, etc., etc.. Paliativos que não resolvem nada, que pretendem apenas, prolongar a pobre vida de um sistema agonizante... Negar a crise da democracia seria negar a evidência, o panorama político da nossa época.» (sublinhados nossos) Salazar o Homem e a sua obra, Lisboa, Empresa Nacional de Publicidade, pp. 67-68. 


\section{Os diálogos de doutrina democrática}

e, em particular, António Sérgio, grande apologista dessas reformas em diversos artigos publicados $\left({ }^{13}\right)$.

Terão sido, certamente, este ataque feito num tom sarcástico e corrosivo, bem como a defesa que o ex-professor fez da instituição da censura, os «detonadores» da réplica imediata do ensaísta, primeiro nos «Retalhos» da Seara Nova e depois nos Diálogos.

Sérgio vai problematizar estas e outras questões sob a forma socrática de diálogos ou palestras entre um Estadista - Salazar - e um Libertário- António Sérgio - para desmontar as ideias e raciocínios do ditador de Santa Comba Dão.

\subsection{Estrutura da obra.}

$O$ texto divide-se, como dissemos, em seis diálogos muito desiguais em extensão, cujo conteúdo ultrapassa frequentemente o que seria de esperar da simples leitura dos seus títulos. Por exemplo no Diálogo Primeiro - «Da Expressão do Pensamento e da Democracia» - o Libertário detém-se longamente na questão religiosa; e no Diálogo Terceiro - «Da Reforma Agraria» - , no problema da instrução.

A forma de diálogo, tão utilizado por certos autores clássicos como Platão na antiguidade, e Galileu no Renascimento, é aqui retomada por Sérgio, que em 1930 já tinha escrito um ensaio dramático em três actos - Antigona - utilizando aquele processo. E não há dúvida que o recurso ao diálogo se adapta, de forma particularmente feliz, ao método pedagógico de Sócrates - a maiêutica - que tinha como objectivo fazer despertar nos espíritos a verdade que contêm em si. Só que, na obra que nos propusemos analisar, as intervenções de uma das personagens, o Estadista, são na sua maior parte excertos de intervenções que essa mesma personagem na vida real, Salazar, fizera nas entrevistas publicadas meses antes. Algumas delas, foram porém recriadas pelo próprio ensaísta, para tornar o diálogo mais vivo, mais próximo da linguagem falada, e prender a atenção do leitor: são geralmente pequenos comentários ou interpelações ao discurso do Libertário, sob a forma de curtas frases.

Quanto às passagens transcritas das entrevistas de Ferro, Sérgio selecciona-as aqui e acolá, não na sequência em que se

$\left.C^{3}\right)$ Nomeadamente nas «Notas de Política», Ensaios III, Lisboa, Sá da Costa, 2. ${ }^{a}$ ed., 1980, p. 148 e p. 155 (l. ${ }^{a}$ ed., Renascença Portuguesa, 1932). Um dos artigos incluídos nesse volume - "Reforma do Legislativo", - escrito em Paris em Junho de 1929, já tinha sido publicado em A Aguia de Jan./Fev. de 1932, e na Seara Nova $\mathbf{n}{ }^{\circ}$ 293, de 7.4.1932. 


\section{António Sérgio}

encontram no livro Salazar o homem e a sua obra mas sim pelo carácter polémico que têm, de acordo com os temas que mais the interessa debater e escalpelizar, sendo-lhe indiferente a organização que aquele jornalista lhe dera.

\section{Principais temas e ideias do «Libertário».}

\subsection{O problema da censura.}

Não é por acaso que o Libertário começa por abordar o problema da censura, dando precisamente como exemplo, o caso de um amigo seu (trata-se evidentemente de António Sérgio) que foi proibido de transcrever na revista de que era director, a Colheita Nova (referência velada à Seara Nova), as listas de créditos extraordinários que o então ministro das finanças (Sinel de Cordes) fraudulentamente concedia a particulares, e que tinham até sido publicados no Jornal Oficial (Diário de Governo). É que foi essa mesma censura que impeliu Sérgio para a oposição decidida ao Estado Novo.

Outro exemplo que o Libertário refere do facciosismo desta instituição é o apoio dado às calúnias que dois jornais reaccionários, um dos quais «católico», tinham lançado sobre um amigo - de novo Sérgio - louvando as violências feitas por um grupo de integralistas, no Teatro de S. Carlos, aquando de uma conferência sua $\left({ }^{14}\right)$.

Assim como a censura está sujeita ao livre arbítrio dos censores, tal acontece com toda e qualquer autoridade que não possa ser criticada, o que prova por si só a «necessidade da democracia» e da doutrina democrática $\left({ }^{15}\right)$.

\subsection{Os meios e os fins. As reformas políticas.}

Esclarecendo a confusão que o Estadista faz entre o ideal democrático e os órgãos da democracia, entre meios e fins, o Libertário salienta a necessidade de aperfeiçoar estes órgãos, como meios para atingir aquele ideal, que considera «eterno, porque deriva da estrutura da consciência humana. A razão exige-o como fim; a experiência, depois, selecciona os meios, aperfeiçoa os órgãos» $\left({ }^{16}\right)$. O que significa que a doutrina de-

( $\left.{ }^{14}\right)$ Tratava-se da conferência «O Clássico na educação e o problema do Latim», proferida por Sérgio em Maio de 1926 naquele salão, e publicada nos Ensaios II, em 1929.

(15) «Diálogos de Doutrina Democrática», Democracia, Lisboa, Sá da Costa, l. ${ }^{\mathrm{a}}$ ed., p. 5.

(16) Ob. cit., p. 7 . 


\section{Os diálogos de doutrina democrática}

mocrática é imanente à própria consciência, é inata, constitui algo de adquirido aprioristicamente.

A ideologia democrática assenta, pois, num racionalismo de cariz idealista, na medida em que promana da "estrutura da consciência» (note-se que o termo estrutura é aqui empregue em sentido abstracto) eéa razão que dita os seus objectivos. E quais são os «fins supremos», eternos, para os quais aponta a razão? Trata-se da «igual dignidade» para todos os homens, do "governo do povo pelo próprio povo», enfim, do ideal cristão dos Evangelhos $\left({ }^{17}\right)$.

O Libertário prossegue então, esmiuçando as contradições em que o Estadista cai, e, depois de expor a sua concepção de democracia - concepção total, em que o político é indissociável do económico, do social e do moral, como veremos - concretiza quais as reformas indispensáveis para renovar e melhorar o funcionamento do regime democrático: a instituição do círculo único para combater o caciquismo, limitações dos tempos de discussão dos projectos, orçamentos, e interpelações no parlamento para evitar «a morosidade» dos debates e o «paleio estéril», dificultar a aprovação de votos de desconfiança ao governo, etc. $\left({ }^{18}\right)$.

Este conjunto de medidas seria tomado por um governo de esquerda, excepcional e transitório, que apoiaria a formação e o desenvolvimento das cooperativas de consumo, lançando deste modo as bases da democracia social.

Tal projecto opõe-se ao simulacro de República que era o regime de Salazar, vigorosamente denunciado por Sérgio: «Regime 'republicano' sem liberdade, sem democratização progressiva da vida pública, do crédito, da economia, da educação; sem fiscalização do governo pelo povo; sem possibilidade de criticar a autoridade, ainda que se obedeça à autoridade; regime 'republicano' sem marcha para a esquerda, numa palavra - não o considero eu como republicano» $\left({ }^{19}\right)$.

A proposta sergiana de uma ditadura reformadora, extraparlamentar e de carácter provisório, permanece, no entanto, vaga e pouco explícita, nomeadamente no que respeita aos meios a que deveria recorrer para levar a cabo a construção da democracia social.

É certo que Sérgio põe a tónica no espírito de esquerda, que deverá nortear a política do governo excepcional e na brevidade da sua existência (....férias de uns meses ao par-

C) $\bullet$ Ob. cit.y pp. 7-8.

$\begin{array}{ll}(18) " & \\ O » & \text { pp. } 9-10 .\end{array}$ 
lamento): não poderemos, pois, acusá-lo de ambiguidade e, muito menos, de cedência de "argumentos ao fascismo», como dá a entender Fernando Farelo Lopes, num artigo recente $\left({ }^{20}\right)$. E se o projecto de «governação exceptional» não é muito claro quanto aos meios práticos, quanto às políticas sectoriais de que se socorreria, a verdade é que, os seus objectivos são bem precisos e inequívocos: melhorar o funcionamento do regime de democracia política através de uma reforma radical do parlamento, desenvolver a democracia social pelo cooperativismo, em suma, «democratizar mais a fundo uma democracia».

Não esquecemos, evidentemente, que, nas referências que faz à ditadura, anteriores à edição original dos Diálogos (designadamente no artigo «Sobre o julgamento do 18 de Abril» da Seara Nova de 24.10.1925), ainda não figura a componente do cooperativismo, que Sérgio só viria a incorporar mais tarde, no seu exílio em França. De qualquer modo, ainda antes do 28 de Maio, a demarcação em relação à ideia fascizante de ditadura, parece ser, da parte do ensaísta, uma preocupação primordial.

\subsection{A liberdade e a autoridade.}

Um tema frequentemente abordado e retomado nos Diá$\log o s$ é o da relação entre a liberdade e a autoridade, o da posição do indivíduo perante o estado.

«A autoridade só se justifica.... quando é um meio para a liberdade» que é «o maior bem duma pessoa, dum ser espiritual» $\left({ }^{21}\right)$, diz o Libertário de acordo com a concepção cristã no Evangelho de S. Lucas, de que cita duas passagens.

Para Sérgio, a liberdade é inerente ao homem e é sobretudo uma noção de carácter moral e espiritual, como o eram a de Proudhon e Antero. O acto de libertar é associado à «verdadeira missão divina» e às acções de «civilizar-se», e de «julgar o governante legítimo» $\left({ }^{22}\right)$.

Mas a liberdade, que só poderá efectivar-se através da democracia social, da igualdade e da fraternidade, está também ligada a determinadas camadas sociais: o povo e os trabalhadores («liberdade do povo»; «liberdade dos trabalhado-

\footnotetext{
$\left.{ }^{(20}\right)$ Fernando Farelo Lopes, «O Liberalismo Decadente da 'Seara Nova' (algumas hipóteses)», $\mathrm{O}$ Fascismo em Portugal. Actas do Colóquio realizado na Fac. de Letras de Lisboa, Lisboa, A Regra do Jogo, 1982, pp. 156-159.

(i) Diálogos... p. 21.

( ${ }^{22}$ Ob. cit., p. 22, p. 25, p. 26.
} 
res») $\left.{ }^{23}\right)$. E o Libertário enuncia a «Regra absoluta da alma livre: nunca aclamar um senhor governante, seja este liberal ou não seja; por maioria de razão, nunca ser tímido diante dele, não sentir por ele 'instintivo respeito' ou 'temor aflitivo' ante o seu contacto: mas conservar uma atitude desprendida, crítica, ainda que concordemos com a sua obra, ainda que o ajudemos na sua acção» $\left({ }^{24}\right)$.

Perante o poder preconiza, pois, uma atitude não emotiva, serena, reflectida, essencialmente crítica e de fiscalização da prática dos governantes (noter-se que os Diálogos são o próprio exemplo vivo desta atitude mental).

Sérgio demarca-se do Estado Novo e do estado bolchevista, ambos estados fortes, que na sua opinião utilizam meios violentos, desprezando a «liberdade individual no campo moral, jurídico e político» $\left({ }^{25}\right)$, mas não deixa de lembrar os seus pontos de contacto com o bolchevismo: na «inspiração social» e na atitude anticapitalista.

A crítica ao regime soviético centra-se em dois pontos: o reforço do aparelho de estado que se verificou na U.R.S.S. e a utilização de meios violentos por parte dos seus dirigentes.

Ora para Sérgio, tal como para Antera, o fundamental na construção da sociedade nova é que os meios a pôr em prática sejam conformes com os objectivos a atingir, com a moral democrática $\left({ }^{26}\right)$.

E o seu humanismo reformista leva-o a distinguir «os que são absolutos por acidente e os que o são por objectivo e por sistema». Dos primeiros aponta como exemplos as ditaduras de Mouzinho da Silveira e a Convenção francesa. Dos segundos a monarquia absolutista de Luís XIV.

\subsection{O socialismo cooperativista.}

A alternativa aos regimes de estado forte que emergiram da profunda crise da sociedade capitalista, encontra-a o ensaísta no socialismo cooperativista, «antiestatal», «liberal ou libertário» $\left({ }^{27}\right)$, (note-se que os adjectivos liberal e libertário são aqui empregues como sinónimos, embora não o sejam: libertário é sinónimo de anarquista), em que coexistem, como hoje diríamos, três sectores económicos (Sérgio emprega o conceito de regimes de economia): as cooperativas de consu-

$$
\begin{aligned}
& \left.{ }_{(24)}^{23}\right) \text { Ob. cit. } y \text { p. } 25, \text { p. } 31 . \\
& \text { (") } " \text { " p.28. } \\
& \text { (") ' " } " \text { p.28. } \\
& \left({ }^{2 T}\right) " \gg>\text { p.35. }
\end{aligned}
$$


mo «para a alimentação, a habitação, o vestuário» etc., a «régie cooperativa para os grandes serviços públicos» como os correios, os transportes etc., e a iniciativa privada, "nara as pequenas indústrias especiais» $\left({ }^{28}\right)$.

Sérgio define o cooperativismo como «o regime económico em que é soberano o consumidor», como "o sistema» em que a produção satisfaz apenas as necessidades do consumidor, «sem lucro para pessoa alguma» $\left({ }^{29}\right)$.

Um dos objectivos do cooperativismo é «fazer desaparecer gradualmente - e com a maior suavidade de processos- o Capitalista, o Vendedor e o Lucro» $\left({ }^{30}\right)$. E como as cooperativas, organizadas numa grande Confederação, pertencem aos próprios operários que produzem tudo para os sócios, os produtos são distribuídos (e não vendidos) pelo custo da sua produção $\left({ }^{31}\right)$.

Aplicando à vida política o princípio da hegemonia do consumidor na vida económica, que se realiza no voto individual de cada consumidor na cooperativa, chega-se ao regime político da democracia, à eleição dos deputados pelos votos individuais.

Por outro lado, o cooperativismo «é a aplicação do ideal democrático no campo da administração da vida económica» $\left({ }^{32}\right)$. Daí que Sérgio considere a democracia política indissociável da democracia económica.

O projecto cooperativista implica uma «socialização prudente» dos mais importantes meios de produção, levada a cabo não pelo estado, mas sim pelas cooperativas de consumo, organizadas em federações nacionais.

O estado deve limitar-se a apoiar os cidadãos neste processo, restringindo-se as suas funções a um «auxílio técnico, legislativo, financeiro e educativo», a uma intervenção nas expropriações e indemnizações, à contratação de técnicos para a administração das cooperativas. Tudo isto através de um Ministério da Cooperação, que é identificado com uma Junta de Organização Cooperativa ou Directoria Geral da Cooperação no Ministério do Trabalho e dos Seguros Sociais. E Sérgio insiste que na Democracia Cooperativa o estado não passa de uma «associação como outra qualquer e de natureza essencialmente caduca» $\left({ }^{3}\right)$, que deve ajudar e não criar.

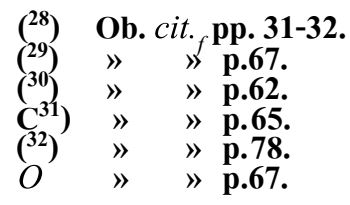




\section{Os diálogos de doutrina democrática}

Mas será que o papel do estado é, no fim de contas, tão limitado, tão passivo como o autor nos pretende fazer crer? Afinal a «assistência técnica, financeira e pedagógica» que ele próprio considera "absolutamente indispensável» $\left({ }^{34}\right)$, não será decisiva, diríamos mesmo determinante, para o desenvolvimento da economia cooperativa?

E como se articula a ajuda do estado com as funções da Federação das Cooperativas? A dependência económica e tecnológica em relação ao estado, não tornaria o papel deste imprescindível?

Parece-nos ser neste ponto, ao subestimar o peso real e a importância do aparelho de estado na sociedade, bem como ao menosprezar as questões políticas, que reside o carácter utópico da teoria sergiana.

Segundo o autor dos Diálogos o cooperativismo vai-se desenvolvendo no seio do próprio sistema económico capitalista, substituindo progressivamente os seus mecanismos, de uma forma pacífica.

Com o desaparecimento gradual do lucro, da concorrência e dos capitalistas, é o próprio estado que se irá atrofiando.

Os sindicatos deixam, então, de ter razão de ser: os trabalhadores participam na gestão económica e os conflitos sociais esbatem-se progressivamente, até ao desaparecimento das classes.

Neste antiestatismo, fortemente marcado pela doutrina liberal clássica e pelos socialismos utópicos, resulta, no entanto, pouco explícita a articulação com o projecto da ditadura reformadora e transitória a que já nos referimos.

O socialismo cooperativista, que se demarca do «socialismo de estado», das escolas que visam «matar o capitalismo à força de pancadas que são decretos, com as armas políticas de que dispõe o estado» $\left({ }^{35}\right)$ revela uma forte influência de Antero e de Proudhon.

Como Antero, Sérgio concebe o económico em função dos objectivos morais. A virtude, o amor da liberdade e da livre iniciativa do indivíduo, o amor do próximo, a recusa dos meios violentos, a sintonia com os ideais do cristianismo original, são características comuns do socialismo dos dois pensadores.

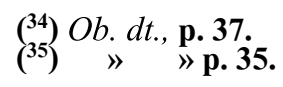


$\mathrm{O}$ aspecto em que Sérgio vai mais longe do que os seus precursores, é quando desenvolve o conceito de federação económica que, segundo ele, estava pouco precisa nas obras daqueles teóricos. $£$ aqui que intervém uma outra influência no seu pensamento; a da chamada escola de Nîmes de que Charles Gide $\left({ }^{36}\right)$ foi um dos fundadores e um dos principais mentores.

Para Charles Gide, era imprescindível que as cooperativas se agrupassem a fim de criar, com os seus fundos de reserva, grandes lojas por grosso, que permitissem uma progressiva auto-suficiência dos seus associados. Os objectivos a atingir, seriam numa primeira fase a substituição do comércio, depois da indústria capitalista, e, por fim, da grande propriedade capitalista. Tal é também o plano de transformações exposto nos Diálogos.

\subsection{A reforma agrária.}

Criticando a confusão que o Estadista faz entre «grande exploração» e "grande propriedade», o Libertário propõe, no Diálogo Terceiro, uma reforma agrária cujos objectivos, salienta, são sempre «morais, as razões da justiça» $\left({ }^{37}\right)$ : orgar nizar os pequenos e médios proprietários em cooperativas de crédito e de consumo, admitindo também a criação de herdades colectivas. A reforma deveria ser orientada por uma Junta de Reforma Agrária para resolver «cientificamente» cada caso concreto no que respeita a indemnizações e ao apoio do estado.

Sérgio baseia este projecto na teorização dos cooperativistas franceses, adaptando-a evidentemente aos problemas estruturais da nossa agricultura, que já tinham sido apontados nor economistas do séc. XVII como Severim de Faria e Luís Mendes de Vasconcelos. Tais autores já chamavam a atenção para a necessidade de uma política de fixação, de apoio à colonização do Alentejo por parte do estado.

$\left.{ }^{3 f l}\right)$ Charles Gide (1847-1932) professor de Economia Política nas Universidades de Bordéus, Montepellier e Paris, no College de France, onde leccionou uma cadeira de Cooperação (1919-1930), e noutros estabelecimentos de ensino, contribuiu com a sua doutrina para a unidade da cooperação em França em que se notou uma forte tendência para a despolitização, desde cerca de 1912. Publicou várias obras, entre as quais Cooperation (1900), Histoire des Doctrines Economiques (1909), Les Sociétés Cooperatives de Consommation (1910), etc..

$\left({ }^{37}\right)$ Diálogos... pp. 40-41. 


\section{Os diálogos de doutrina democrática}

2.6. A instrução.

Além da assistência técnica, a reforma agrária encontra um complemento indispensável numa «verdadeira instrução primária» que não se limita a ensinar a $1 \mathrm{er}$, escrever e contar, mas que eduque o cidadão para a liberdade e para o trabalho cooperativo $\left({ }^{38}\right)$.

A futura escola rural deve basear-se nas necessidades concretas dos lavradores e integrar-se no meio para formar o «agricultor - cidadão», ou seja, o lavrador que conscientemente intervém na «cousa pública».

Sérgio preocupa-se, sobretudo, com a criação de uma nova mentalidade dos professores, com a modificação dos programas das escolas normais, nos quais deverão ser introduzidas a pedagogia, a psicologia, o estudo da agricultura, da economia rural e o inglês.

Opondo-se ao obscurantismo salazarista, este programa de alfabetização é traçado com o objectivo bem explícito de alargar as elites que, segundo o autor, eram demasiado restritas em Portugal, de seleccionar os mais inteligentes numa base mais larga.

Em última análise, o progresso da grei depende da cultura das elites.

Pela importância que atribui à educação do povo, à instrução primária, pelos métodos que propõe de participação activa do aluno, de self-government escolar, Sérgio enquadra-se na corrente da pedagogia liberal em que o pedagogo norte-americano John Dewey ${ }^{39}$ ) não terá deixado de exercer notável influência.

$\left.{ }^{38}\right)$ Ob. cit., p. 46.

( $\left.{ }^{311}\right)$ John Dewey (1859-1952), pedagogo e filósofo norte-americano. Criou uma escola experimental na Universidade de Chicago (1894-1904), onde pôs em prática a sua concepção de educação: introduziu as ocupações activas na acção individual e em cooperação de grupo, para que a escola se inserisse na sociedade, tentando atingir três objecti vos: 1. Ligá-la intimamente ao lar e ao meio ambiente da criança; 2. dar à História, à Ciência, e à Arte um valor positivo e real na sua vida; 3 . praticar a leitura, a escrita e o cálculo, com base na experiência e nas ocupações quotidianas. Inicialmente adepto de um idealismo neo-kantista, veio a desenvolver mais tarde uma filosofia pragmatista, baseada na teoria de W. James. Escreveu uma imensa obra, da qual destacamos: My Pedagogical Creed (1897), Ethics (1908) e Democracia e Educação. 


\section{Antonio Sérgio}

Por outro lado, ao projecto de criação de uma instrução primária superior - com o objectivo de formar quadros intermédios, dotando-os de uma cultura geral e de uma especialidade técnica - não é estranho o conhecimento da experiência das chamadas escolas de continuação alemãs, criadas por Kerschensteiner $\left({ }^{40}\right)$.

\subsection{A moral democrática. O idealismo ético.}

Pode dizer-se que, no discurso do Libertário, as razões e os fins de ordem moral, são uma constante, frequentemente invocados, explícita ou implicitamente.

Assim, o Libertário fala da «preeminência das razões morais», considera-as, como vimos, as principais razões da reforma agrária - associando-se às «razões de justiça»-, afïrmando que, «a emancipação económica não passa.... de um simples meio de emancipação moral» $\left({ }^{41}\right)$.

A noção de moral associa-se às noções de espírito, alma e ordenação intrínseca da consciência, opondo-se a conveniência política, a matéria, a cousas, a ordenação coisista, mater rial, visível, à chamada «aberração jesuítica», que sacrifica os valores de ordem moral à obediência do espírito.

No domínio económico, opondo-se ao lucro, que está na origem da «perversão das almas», que "desmoraliza os homens», a «vida moral exige» a «liberdade do trabalhador», a sua «participação na direcção económica» $\left({ }^{42}\right)$.

Para além destas referências explícitas à moral, os Diálogos estão eivados de toda uma série de valores éticos e de normas de conduta. A partir de uma raiz doutrinal, o princípio essencial da Democracia - o respeito pela dignidade da pessoa humana - o Libertário desenvolve no Diálogo Quarto- «Do Maquiavelismo e do Jesuitismo» - um discurso em que os valores e normas que os verdadeiros democratas deverão adoptar, se opõem ao maquiavelismo e ao jesuitismo, padrões de comportamento característicos dos jesuítas, tiranos, mandões, fascistas, e, também dos falsos democratas.

É interessante confrontar em duas colunas estes «corpos» de valores e regras morais (vide Apêndice A, p. 74), em

$\left.{ }^{40}\right)$ Vide «Um inquérito», Seara Nova, n. ${ }^{\circ} 300$, 26.5.1932.

(41) Diálogos... pp. 40-41.

$\left.{ }^{42}\right)$ Ob. cit., p. 76. 
que as aposições, as associações e identidades de conceitos se tornam nítidas: na coluna da esquerda, inscreveram-se os preceitos e valores da moral democrática; na da direita, as atitudes jesuíticas e maquiavélicas, caracterizadas e julgadas, como é óbvio, do ponto de vista ético, por Sérgio. Sublinhámos os termos que exprimem de algum modo valores morais, opostos ao jesuitismo e ao maquiavelismo (só os três primeiros termos foram sublinhados pelo autor).

Esta teorização não se limita a estabelecer determinados princípios ideológicos por oposição ao jesuitismo e ao maquiavelismo. Sérgio prescreve, como moralista, todo um conjunto de atitudes e comportamentos aconselháveis, segundo a doutrina democrática.

Subjacente a esse corpo de preceitos, encontra-se um padrão de vida, uma maneira de estar no mundo, uma determinada coerência conforme com o ideal dos Evangelhos, com o exemplo de Cristo. Por isso, Sérgio não pode poupar a incoerência dos democratas que não são verídicos, e muito menos a «aberração jesuítica». Por isso demarca-se frequentemente desses falsos democratas, de certos moralistas que se deixaram seduzir pelos vícios materiais, pela «conveniência política», pela «ideia de passar por cima de tudo». (Para acentuar essa demarcação, antepõe o adjectivo verdadeiro aos nomes democrata e moralista).

Lembre-se que são também questões morais - questões de justiça-que constituem a pedra de toque para o ensaísta distinguir os homens de esquerda dos homens de direita: o homem de direita é o «que mostra a preocupação constante em não desagradar aos poderosos»», enquanto o de esquerda «em questões de justiça, não se importa de desagradar aos poderosos, à Alta Traficância, à Ganância Alta.... não deixa tudo para as calendas gregas» $\left({ }^{43}\right)$.

Estabelecendo um código de condutas sistematizado, o autor dos Diálogos acaba no entanto por cair em certos juízos de valor taxativos, e por resvalar num acentuado maniqueísmo («doutrina boa», "doutrina péssima», «mau democrata», «maus católicos», etc.).

Mas voltemos à questão da raiz doutrinal, das origens do ideal democrático. Uma das ideias-chave do Libertário é expressa, quando refutando a comparação que o Estadista

( $\left.{ }^{43}\right)$ Ob. cit., p. 43. 
faz entre as escolas políticas e as escolas literárias - na sua opinião seriam ambas passageiras - aquele lhe responde que essa comparação não se pode aplicar ao «ideal democrático» que é «eterno». Mais à frente, depois de se declarar várias vezes idealista, o Libertário volta a abordar a questão da origem das teses da democracia, que tal como em Antero, procedem da «Revelação da Consciência». Isto é, constituem algo de absoluto e universal, algo de referente ao «Eu espiritual, originário e puro». E é uma «dedução filosófica e idealista que leva da análise da consciência até à política da democracia» $\left({ }^{44}\right)$.

Infelizmente, porém, não aprofunda mais o problema, deixando o leitor pouco esclarecido. Afinal como se processa esta dedução filosófica, como se opera a passagem da análise da consciência aos princípios democráticos? Compreendemos melhor esta explicação, quando Sérgio afirma que a democracia é a "tradução política do Evangelho», que o seu ideal é «homogéneo com o da religião cristã», que, «tem o carácter de uma religião», ou ainda quando aceita e recupera a noção de «mística democrática», a que se referira o Esta$\operatorname{dista}\left({ }^{45}\right)$.

\subsection{A concepção de civilização.}

Também no que respeita ao conceito de civilização, Sérgio diverge profundamente da concepção eclética e tradicionalista de Salazar: reclama-se do verdadeiro cristianismo, da noção de civilização interior do Novo Testamento, em sintonia com o lema da Revolução Francesa: Fraternidade, Igualdade, Liberdade (Sérgio inverte a ordem dos termos para frisar que a Liberdade só é alcançável através da Fraternidade e da Igualdade).

Confrontemos, seguindo o discurso do Libertário, as duas ideias opostas de civilização:

O Ob. eit., p. 76.

$\left({ }^{46}\right) \quad "$ pp. $7,10,75$. 


\section{LIBERTÁRIO}

— ideia de civilização interior que domina nos Evangelhos, com as seguintes virtudes aplicáveis no cooperativismo:

* veracidade

* fraternidade

* igualdade

* amor ao próximo como a nós mesmos

- ideia de civilização de natureza francamente

* cristã

* interior

* dinâmica

* racionalista

- novo tipo de civilização/Sociedade de Nova; fundado

* nos princípios do amor fraterno

* nele será possível o ser verídico

— Religião do Novo Testamento (*)

* universal

* espiritualista

* de liberdade

* de paz

\section{ESTADISTA}

— simples conservação da sociedade passada ou

- simples combinação de cousas passadas e escolhidas em diferentes épocas: séc. XVII, Idade Média, Roma, etc.

- por meio de jogos malabares mais ou menos maquiavélicos e graças a uma confusão inextricável de palavreados contraditórios;

— Religião do Antigo Testamento:

* nacional

* materialista

* de servidão

* de luta

Esta concepção de civilização racionalista e mística, na encruzilhada da moral cristã com a tradição liberal, remete-nos para a posição que Sérgio adopta perante a religião cristã e perante os «transviados», os «maus católicos», os católicos reaccionários. O seu objectivo essencial é recuperar o "verdadeiro» espírito religioso, purificar os ideais do cristianismo, tão adulterados pelos católicos de direita. Por isso, denuncia veementemente a apropriação abusiva que eles fazem do catolicismo, com fins meramente políticos, de ordem material. Na sua opinião, só os ideais democráticos, de esquerda se coadunam com a moral cristã.

(*) Sérgio associa o contraste entre os dois conceitos de civilização com o contraste do Novo Testamento com o Antigo Testamento. 


\title{
Antonio Sergio
}

\begin{abstract}
«A simplicidade de expressão só se atinge por um complexo, dificil trabalho de arquitectura, feito numa massa comple$x a$ de produtos espirituais.... $O$ difuso $e$ redundante não são riqueza de conteúdo: são pobreza de ordenação. Existe a simplicidade rica, como existe a complexidade pobre.»

António Sérgio, Ensaios III, Lisboa, Sá da Costa, 2. ${ }^{a}$ ed., 1980, p. 245.

«...quando se trata de confrontar teorias, analisando-as e discutindo-as, a forma dialogai é a mais cara, a mais simples, a mais directa, já que cada uma de tais doutrinas se expressa por cada um dos interlocutores.»
\end{abstract}

António Sérgio, Ensaios $V$, Lisboa, Sá da Costa, l. ${ }^{a}$ ed., 1973, p. 123.

\section{AS ALTERAÇÕES E ACRESCENTOS MANUSCRITOS (1945?/ /1958?)}

1. Os critérios utilizados.

O estudo comparativo da versão original do texto (1933), com as alterações que posteriormente foram introduzidas por António Sérgio, constitui um meio privilegiado para o estudo da evolução do seu pensamento e das formas de expressão que utiliza.

Tal análise pode ser bastante elucidativa acerca das preocupações mais «reconditas») do criador do texto, da vigilância crítica que exerce sobre si próprio, das particularidades de expressão que prefere.

Levantam-se, porém, alguns problemas numa abordagem comparativa deste tipo. Como analisar um número total de 431 anotações manuscritas introduzidas por Sérgio no seu exemplar dos Diálogos de Doutrina Democrática? Como abordar tão elevado número de correcções - supressões ou variantes - e acrescentos, na sua imensa diversidade, naquilo que respeita ao sentido que lhes está subjacente, ao objectivo ou objectivos que nortearam o ensaísta, quando decidiu redigi-las?

Após um levantamento sistemático de todas as anotações, devidamente integradas nos respectivos contextos —única maneira de as entender na complexidade das suas implicações - procedemos a uma classificação exaustiva dos registos manuscritos, de acordo com uma grade em que incluímos os diversos tipos de transformações, segundo os objectivos visados. 


\section{Os diálogos de doutrina democrática}

Qual (is) o (s) critério (s) para considerar a existência de uma anotação?

Do ponto de vista da extensão das anotações, optámos por considerar indescriminadamente todas as alterações e acrescentos, independentemente de constituirem uma só palavra, frase ou texto, mais ou menos longo. Critério discutível, certamente. Mas estamos em crer que, uma eventual classificação das anotações consoante a sua extensão (poder-se-ia por exemplo distinguir três grupos: palavras, frases e textos) introduziria uma certa margem de indefinição, na medida em que, por vezes, é extremamente difícil delimitar rigorosamente os conceitos de frase e de texto. Vários critérios poderiam então ser utilizados para classificar os «casos difíceis», uma vez que existem várias noções de frase e texto.

Por outro lado, resolvemos não descriminar as variantes, as supressões e os acrescentos em análises independem tes. Por diversas razões: 1 . Há vários acrescentos que estão intimamente relacionados com variantes e/ou supressôes, sendo impossível muitas vezes entrever o seu sentido, os seus objectivos, sem ter em conta a alteração, ou alterações que os antecedem (é o caso da $3 .^{\mathrm{a}}$ variante do texto $n .^{\circ} 1$ que incluímos no Apêndice D, p. 79). 2. Quer as variantes, quer as supressões e acrescentos, obedecem em grande parte aos mesmos tipos de objectivos e preocupações do autor. 3. Finalmente, não sabemos com precisão quando foram redigidas a maior parte das anotações. Se há acrescentos que foram introduzidos na sequência de certas variantes, adequando o discurso ao «espírito» destas, ou vice-versa, se outros podem ser facilmente datados, ainda que com alguma margem de incerteza - como é o caso do que faz referência ao estado do Ghana $\left({ }^{46}\right)$, assim designado desde a independência em Março de 1957, ou da referência ao bispo do Porto, como exemplo de um verdadeiro católico $\left({ }^{47}\right)$, - a verdade é que, a esmagadora maioria das anotações oferece grandes dificuldades quanto à sua datação, ou é totalmente impossível datá-las com exactidão.

Tudo nos leva a crer, de acordo com Augusto Abelaira e Idalina Sá da Costa, que tenham sido elaboradas em dois momentos diferentes $\left({ }^{48}\right)$.

O primeiro foi, certamente, no rescaldo da vitória dos aliados em Maio de 1945: o Estadista, numa das suas intervenções, na versão original, refere-se a um discurso «pronun-

$\left.C^{G}\right)$ Ob. cit., p. 24.

$\left.{ }^{n}{ }^{48}\right)$ Vide «Da presente edição», Democracia... p. IX-X. 
ciado por Mussolini há mais de dez anos», passagem esta que viria a ser alterada para «há mais de vinte anos» $\left({ }^{49}\right)$. Ora esse discurso foi, muito provavelmente, proferido pelo duce em Outubro de 1922, pouco antes da marcha sobre Roma. Pensamos que a anotação deve ter sido escrita em 1945, talvez entre Setembro, quando o governo anunciou eleições livres e dissolveu a Assembleia Nacional, e Novembro (mês das eleições). Lembre-se que durante a campanha eleitoral em que participou o MUD, a actividade da censura diminuiu bastante, embora por um curto espaço de tempo. E natural portanto que Sérgio tivesse pensado então na hipótese de publicar os Diálogos. Pouco depois, voltava a intensificar-se a feroz repressão às tentativas dos democratas para fazerem ouvir a sua voz.

$\mathrm{O}$ segundo momento, foi sem dúvida aquando do lançamento da candidatura de Humberto Delgado $\left({ }^{50}\right)$, como parecem querer indicar as já aludidas referências ao estado do Ghana, e ao bispo do Porto. Por outro lado, a atribuição nas anotações do nome de Manuel ao Estadista, bem corno as formas de tratamento familiar que geralmente o acompanham, são muito próximas das utilizadas no Pátio das Comédias. Ora nesta obra, igualmente em forma de diálogo, publicada em 1958, existe uma personagem chamada Manuel, doutor de Coimbra, que também encarna o ditador Salazar, e abundam expressões e formas de tratamento próprias da linguagem familiar.

Estamos pois em crer que, pelo menos aquelas anotações dos Diálogos tenham sido redigidas na altura da elaboração do Pátio das Comédias. Para isso aponta, ainda, um lapso em que o Libertário trata o Estadista por «meu sobrinho», forma utilizada pela Tia Joaquina do Pátio das Comédias.

Torna-se assim, como é óbvio, impossível classificar as anotações de acordo com a data em que foram feitas.

Ao proceder à sua interpretação deparámos com outros problemas de método. Referimo-nos à dificuldade em classificar algumas delas segundo os objecti vos que se foram definindo por diversos tipos, à medida que prosseguíamos o nosso inventário das transformações feitas pelo autor.

$\mathrm{Na}$ verdade, muitas variantes e acrescentos obedecem a mais do que um objectivo. É o caso da interpolação a uma passagem em que o Libertário denuncia o propósito do Estadista

( ${ }^{40}$ Diálogos, p. 79.

$\left.\mathrm{C}^{50}\right)$ Segundo Oliveira Marques, a candidatura de Delgado, terá sido pressionada por António Sérgio. Vide História de Portugal, vol. III, Lisboa, Palas ed., p. 397. 
de apenas pretender «fazer homens de iniciativa mas só com iniciativa económica, crematística para fazer dinheiro [e sabe-se que o teu regime se caracteriza pela existência dos tubarões voracíssimos, que significa o auge do predomínio do Alto Tratantismo em Portugal»A $\left({ }^{51}\right)$. Este acrescento visa simultaneamente, explicitar melhor a ideia anterior, dando o exemplo concreto do «regime económico» do Estado Novo, reforçar a denúncia da contradição em que o Estadista cai, querendo apenas «valores sociais autónomos» no campo da economia e não no da política, e também tornar mais vivo o discurso, recorrendo a termos de linguagem familiar.

Optámos por incluir estes casos no tipo de objectivo considerado mais importante. No exemplo dado é, nitidamente, o de reforçar a denúncia da política económica de Salazar.

Mas comecemos por proceder a uma primeira abordagem de conjunto da distribuição das anotações pelo texto.

2. Distribuição quantitativa das anotações pelos seis diálogos e pelos discursos do Libertário e do Estadista.

As anotações manuscritas, (num número total de 431 variantes, supressões e acrescentos), introduzidas na edição original, encontram-se muito desigualmente distribuídas ao longo da obra.

Limitamo-nos a comentar brevemente os números mais significativos, para uma compreensão da prática de auto-disciplina crítica que Sérgio exercia sobre os seus textos.

Naquele total - no qual se incluem 162 acrescentos verificámos que:

1. A maioria das anotações (254, ou seja, cerca de 59\%), foi introduzida nos dois primeiros diálogos.

2. A esmagadora maioria (416 anotações) encontram-se, como é natural, no discurso do Libertário, enquanto que nas intervenções do Estadista - na sua maior parte citaçoes transcritas das respostas de Salazar às entrevistas de António Ferro - só detectámos 15.

Embora nos pareça óbvio e natural que se verifique este desiquilíbrio na persistente prática crítica do autor, não será extemporâneo realçar que as pequenas (pequenas quer no que respeita ao quantitativo, quer ao significado) correcções no discurso do Estadista, são um indício evidente de que o autor dos Ensaios não viu, passados que foram mais de

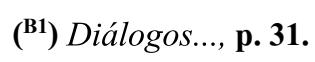


vinte e cinco anos entre a primeira edição dos Diálogos e a data das últimas anotações (1958), necessidade de alterar, significativamente, a linguagem e o pensamento do ditador, que permanecem no seu implacável imobilismo, durante a longa existência do Estado Novo.

3. Nota-se um certo «abrandamento» da vigilância de Sérgio sobre os últimos diálogos, patente não só numa acentuada diminuição da frequência das anotações - nos quatro últimos Diálogos, que ocupam cerca de 45 páginas, só encontramos 155, enquanto nos dois primeiros, que ocupam cerca 32 páginas, há 276 anotações - mas também em certos lapsos em que incorre, como por exemplo, quando o Libertário trata o Estadista por «Miguelzinho» $\left.{ }^{52}\right)$, por «meu sobrinho» $\left({ }^{53}\right)$, ou quando, no princípio do Diálogo $\mathrm{V}$, faz preceder os nomes das personagens por artigos definidos (O Estadista, O Libertário).

Tal abrandamento, verifica-se também na ausência de correcções, que seria «natural» que fossem introduzidas, para se adequarem às anotações anteriormente feitas. Exemplos destes «silêncios» do autor são, nomeadamente, os casos em que mantém o conceito de interior («disposição interior dos homens»; "melhoramento interior») relativamente ao espírito, (conceito esse que substituiu, como veremos, noutras passagens) ou quando não actualiza uma pequena passagem acerca da repressão da ditadura de Mussolini e do regime nazi alemão aos sociais democratas: «dá--se caça aos sociais democratas nas margens do Tibre e para lá do Reno» $\left({ }^{54}\right)$.

4. O Diálogo Quinto contém apenas 5 alterações, sem dúvida, devido ao facto de já ter sido publicado na Seara Nova, em finais de Abril de 1933, e depois cuidadosamente corrigido para a edição original dos Diálogos $\left({ }^{55}\right)$.

$\left(\begin{array}{l}52 \\ 53\end{array}\right)$ Ob. cit, p. 18.

(53) " p. 41, p. 69 e p. 81.

$(54) "$ " 7 . 74.

(55) Repare-se também que este é o único diálogo em que a primeira personagem a intervir é o Estadista. 
DISTRIBUIÇÃO QUANTITATIVA DAS ANOTAÇÕES PELOS DIÁLOGOS E PELAS INTERVENÇÕES DO «LIBERTÁRIO» E DO «ESTADISTA»

\begin{tabular}{|c|c|c|c|c|c|}
\hline & \multicolumn{2}{|c|}{ Correcções } & \multicolumn{2}{|c|}{ Acrescentos } & \multirow[t]{2}{*}{ Totais } \\
\hline $\begin{array}{r}\text { Discursos } \\
\text { Diálogos }^{\wedge \wedge}{ }^{\wedge}\end{array}$ & $\begin{array}{l}\text { Discurso do } \\
\text { «Libertário» }\end{array}$ & $\begin{array}{l}\text { Discurso do } \\
\text { «Estadista» }\end{array}$ & $\begin{array}{l}\text { Discurso do } \\
\text { «Libertário» }\end{array}$ & $\begin{array}{l}\text { Discurso do } \\
\text { «Estadista» }\end{array}$ & \\
\hline $\begin{array}{l}\text { Diálogo } \\
\text { Primeiro }\end{array}$ & 91 & 3 & 52 & - & 146 \\
\hline $\begin{array}{l}\text { Diálogo } \\
\text { Segundo }\end{array}$ & 68 & 1 & 61 & - & 130 \\
\hline $\begin{array}{l}\text { Diálogo } \\
\text { Terceiro }\end{array}$ & 33 & 1 & 23 & - & 57 \\
\hline $\begin{array}{l}\text { Diálogo } \\
\text { Quarto }\end{array}$ & 41 & 2 & 18 & - & 61 \\
\hline $\begin{array}{l}\text { Diálogo } \\
\text { Quinto }\end{array}$ & 1 & 2 & 2 & - & 5 \\
\hline $\begin{array}{l}\text { Diálogo } \\
\text { Sexto }\end{array}$ & 20 & 6 & 6 & - & 32 \\
\hline TOTAIS & 254 & 15 & 162 & - & 431 \\
\hline
\end{tabular}

3. Os diversos tipos de transformações.

A grade classificativa que elaborámos inclui nove tipos de transformações do texto original:

1. Definição mais exacta das ideias; neste grupo distinguimos ainda dois sub-tipos, embora por vezes se tome pouco nítida a sua identificação;

1.A explicitação de ideias

1.B precisão de ideias ou conceitos

2. Reforço de ideias (ênfase);

3. Atenuação de ideias; 


\section{Antonio Sérgio}

4. Não repetição de palavras, ideias ou sons; supressão de textos

5. Simplificações e alterações formais;

6. Introdução de palavras características da linguagem familiar;

7. Variantes características da linguagem cuidada;

8. Recurso à ironia ou ao humor;

9. Actualizações;

Descriminámos ainda, mais dois grupos de anotações que não constituem transformações, ou que levantaram problemas de fixação do texto aos organizadores da edição crítica das Obras Completas:

10. Lapsos do autor;

11. Correcções cuja versão original é ilegível ou oferece dúvidas; frases escritas ao alto das páginas;

Nos apêndices finais, incluímos:

A. O confronto, em duas colunas, (a que já nos referimos) dos valores e regras da moral democrática, com os comportamentos característicos do jesuitismo e do maquiavelismo (ideias contidas nos Diálogos Quarto, Quinto e Sexto) (pp. 72-77);

B. O inventário das ideias e aspectos teóricos reforçados pelo autor, nas anotações manuscritas (pp. 77-78);

C. O inventário das ideias atenuadas (p. 78);

D. Uma amostragem dos diversos tipos de transformações que referimos, nos respectivos contextos (na coluna da esquerda, encontram-se as versões originais, entre barras no caso de terem sido substituídas, ou antecedidas por notas se foram suprimidas; na coluna central transcreveram-se os textos mais significativos da edição anotada, destacando-se entre parêntesis rectos os acrescentos; na coluna da direita registamos os objectivos das transformações verificadas da edição original para a versão anotada);

E. Uma listagem dos temas dos pequenos textos interpolados por Sérgio na edição original (p. 89);

Salvo indicação em contrário nas notas finais, as palavras colocadas entre parêntesis rectos nas citações que fazemos, correspondem aos acrescentos introduzidos por Sérgio.

\subsection{Definição mais exacta das ideias}

Registou-se neste primeiro grupo todos os casos (178, ou seja cerca de $41,3 \%$ do total), em que Sérgio procura precisar o significado de um termo ou de uma ideia, passando 
por vezes de um a vários significantes, ou simplesmente introduzindo uma preposição ou uma conjunção que clarificam o sentido das frases.

\section{IA. Explicitação de ideias}

Detectaram-se 43 casos de transformações, que têm por objectivo tornar as ideias mais inteligíveis, mais fáceis para o leitor comum.

Nas anotações, Sérgio introduz frequentemente exemplos concretos, que completam ou comprovam os seus raciocínios. É o caso da referência à primeira República (vide apêndice $\mathrm{D}$, Texto n. ${ }^{\circ} 1$ p. 79), que é um exemplo de que «a democracia política e a democracia económica [se] pressupõem reeiprocamente» $\left.{ }^{56}\right)$.

Por vezes especifica certas preposições gerais, desce de um nível mais abstracto, para o concreto. É o caso da explicitação da reforma política que visa «estabelecer condições muito severas para a aprovação dos votos de desconfiança, [só lhes dando efectividade 48 horas depois de haverem alcançado maioria na Câmara, se o grupo de deputados que votou a desconfiança puder apresentar nesse lapso de tempo uma lista completa para um ministério novo;»] $\left({ }^{57}\right)$.

Acrescenta predicados, em que os raciocínios se tomam menos abstractos do que nas versões do original, como por exemplo, quando explica em que consiste a «predilecção por um Estado forte [quer dizer, pela tirania dos magnates do Estado»] $\left({ }^{58}\right)$.

Acrescenta nomes, por vezes sinónimos: «a autoridade só se justifica pelo fim [ou obiectivo] que se propõe» $\left({ }^{59}\right)$; outras, identificações: «as principais razões de uma reforma agrária.... são sempre para nós as razões morais [as razões de justiça») $\left({ }^{60}\right)$.

Introduz comparações: é o caso da comparação entre o desenvolvimento do cooperativismo na sociedade capitalista e o desenvolvimento do capitalismo no seio da sociedade senhorial $\left({ }^{61}\right)$.

Acrescenta pequenos textos como o que incluímos no Apêndice D (texto n. ${ }^{\circ} 8$ ), em que faz contrastar a prática de Cristo, com a dos homens do Estado Novo.

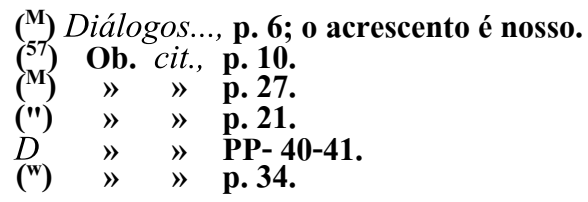


Substitui pronomes por nomes: «O dono de 10.000 hectáres pode tratar aquele ( $o$ homem, na anotação manuscrita) que nada tem em termos onde a dignidade do desprovido não seja suficientemente respeitada...» $\left.{ }^{62}\right)$.

1B. Precisão de ideias ou conceitos

$\mathrm{Na}$ procura meticulosa e incessante das palavras exactas para traduzir o pensamento, Sérgio emprega variadíssimos recursos, sempre preocupado com a definição rigorosa, cartesiana das suas ideias.

Considerámos precisões, todas as transformações que tornam a ideia ou o termo em causa mais exactos na sua definição, ou que tornam menos extensa a significação de uma palavra. Pode-se verificar também uma maior clarificação do sentido, e em certos casos, uma maior abstracção.

Recenseámos os seguintes recursos:

- a substituição de conceitos; a transformação mais frequente, é a que decorre do abandono da terminologia exterior/interior, referente respectivamente ao mundo exterior e ao intelecto; registámos as várias alterações:

\begin{tabular}{|c|c|c|}
\hline VERSÃO ORIGINAL & VERSÃO REVISTA & \\
\hline $\begin{array}{l}\text { conveniências exteriores e ma- } \\
\text { teriais } \\
\text { disciplina exterior } \\
\text { conformidade de natureza } \\
\quad \text { exterior } \\
\text { aparência exterior } \\
\text { efeito externo } \\
\text { obediência externa } \\
\text { ordenação exterior, material, vi- } \\
\text { sível } \\
\text { ordem interior da alma } \\
\text { sociabilidade interior e do espírito } \\
\text { verdade interior do espírito } \\
\text { verdade interior } \\
\text { ordenação interna } \\
\text { obediência interior }\end{array}$ & $\begin{array}{l}\text { conveniências plutocráticas } \\
\text { disciplina sensível } \\
\text { conformidade de natureza } \\
\quad \text { material } \\
\text { aparência sensível } \\
\text { efeito sensível } \\
\text { obediência sensível } \\
\text { ordenação coisista.... } \\
\text { ordem invisível da alma } \\
\text { sociabilidade intrínseca.... } \\
\text { verdade } \text { intrínseca.... } \\
\text { veracidade do espírito } \\
\text { coerência íntima } \\
\text { obediência } \text { do espírito }\end{array}$ & \\
\hline
\end{tabular}

(C2) Ob. cit.y p. 41.

$\left({ }^{63}\right)$ " " p. 13, pp. 53-54, p. 55, p. 56. 
As noções de interior e exterior, relativas à psique (à alma) e ao mundo exterior, foram acerbamente criticadas por Sérgio nas Cartas de Problemática, Carta $n .^{\circ} 2$, por serem consideradas inadequadas à complexa actividade espiritual: «....há corpos exteriores ao nosso próprio corpo, mas.... é pleno absurdo o concluir daí serem eles exteriores à actividade psíquica, exteriores à consciência, à qual não pode fazer sentido o aplicar as relações de fora e de dentro» $\left({ }^{64}\right)$. Daí a sua substituição por diversos significantes que enriqueceram substancialmente o texto.

- a substituição ou interpolação de expressões ou frases como por exemplo: "A história não se repete; todavia, através das sinuosidades da sua marcha, há um rumo geral (ideal humano, na anotação) para que se dá o avanço» $\left({ }^{65}\right)$.

- a substituição, supressão ou acrescento de nomes: é o caso da «Regra absoluta do homem (alma, na anotação) livre» (Texto n. ${ }^{\circ}$ 9, p. 83), da restrição desta regra aos governantes, eliminando os «homens públicos»e os «políticos», categorias estas mais extensas do que aquela, ou ainda, da seguinte frase interrogativa: «Pergunta aos [chefes] industriais como se diminui o custo de um produto?» $\left({ }^{66}\right)$.

- a substituição de verbos ou a modificação dos tempos verbais, por exemplo quando se refere à expropriação das empresas «a fim de as transformar (entregar, na anotação) em cooperativas», ou o Estadista exclama: «Mas era (seria, na anotação) uma guerra!» $\left({ }^{67}\right)$.

- a interpolação de adjectivos: ao afirmar que a Democracia Cooperativa suplanta «finalmente, o [grande] capitalismo agrário» (Texto n. ${ }^{\circ} 13$, p. 86) ou quando diz que o Estado deve expropriar «com indemnização o maior número de [grandes] empresas privadas que se iriam transformando em cooperativas....» $\left({ }^{68}\right)$; note-se que aqui o autor restringe a acção do Cooperativismo aos grupos económicos mais poderosos.

- os substitutos pessoais - pronomes - mudam, aproximando o locutor do seu enunciado; é o que se verifica no trecho em que o Libertário expõe o seu projecto de governo excepcional e transitório (Texto n. ${ }^{\circ} 3$, p. 80-81): os pronomes pessoais e o verbo enunciador passam do plural (nós, nosso,

$\left(^{64}\right)$ Cartas de Problemática... Carta n. ${ }^{\circ}$ 2, Lisboa, Ed. Inquérito, Out. 1952, p. 3.

(60) Diálogos..., p. 79.

(60) Ob. cit., p. 10.

D» $"$ p. 33.

$\left({ }^{68}\right) » "$ p. 35 . 


\section{Antonio Sérgio}

admitimos) para o singular (mim, meu, admito), e aparece um outro verbo enunciador (do que chamo); estas transformações alteram a modalização, tornando as ideias menos categóricas, pessoalizando o discurso. Mas verifica-se, também, uma transformação que podemos considerar oposta a esta: a demarcação do locutor em relação ao seu enunciado «Não me devo esquecer que és ( que te dizes na anotação) católico») $\left({ }^{69}\right)$.

- Novos conceitos. A par do desaparecimento dos conceitos de tirania e de tirano, inadequados em relação às realidades a que se referiam (o regime de Mussolini, o regime dos bolchevistas, e os dirigentes soviéticos) (Texto n. ${ }^{\circ} 10$, p. 84), novos conceitos surgem nas anotações: fascista (inteligência fascista, por oposição à «inteligência democrática») $\left.{ }^{70}\right)$, marxismo (substitui o conceito mais restrito de holchevismo para reforçar a ideia de que a Antiguidade nunca fez a experiência do comunismo, ao contrário do que pretende fazer crer Salazar) $\left(^{71}\right)$, classe operária (substitui o conceito de trabalhadores, mais amplo e menos específico, a propósito das funções da escola, uma das quais deverá ser «uma vida mais higiénica, mais culta, mais rendosa, mais solidária, mais feliz

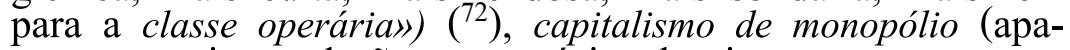
rece numa interpolação, a propósito dos interesses a que estão ligados os «maus católicos») $\left(^{73}\right)$, e esquerdista (compara um católico «que empreenda uma obra de verdadeira esquerda» com «os demais esquerdistas») $\left({ }^{73}\right)$.

- são tambem introduzidas novas designações científicas: Junta de Escolas Experimentais (designação mais específica e precisa do que Junta de Propulsão dos Estudos, na edição primitiva), e Directoria Geral do Cooperativismo no Ministério do Trabalho e dos Seguros Sociais alternativa ao Ministério da Cooperação ou Junta de Organização Cooperativa $\left({ }^{74}\right)$; esta nova terminologia, mais actualizada e precisa, adequa-se melhor aos propósitos de rigor do autor.

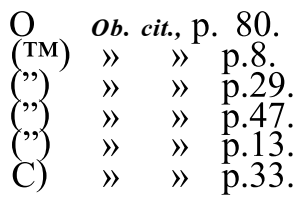




\subsection{Reforço de ideias (ênfase)}

António Sérgio recorre a uma grande diversidade de processos para realçar determinadas ideias ou palavras.

Os 85 casos que incluímos neste grupo (cerca de $20 \%$ do total de anotações) revelam-nos uma notavel subtileza, uma aguda sensibilidade na selecção dos vocábulos mais apropriados para exprimir as ideias a que o ensaísta pretende dar ênfase. Registámos os processos mais utilizados:

- a adjectivação: o acrescento de adjectivos particularmente intensos e expressivos como repelente, pútrido, cálido (Texto n. ${ }^{\circ} 6$, p. 82) ou a sua substituição por outros mais sugestivos - «as revoluções reaccionárias parecem-te sempre boas» (magníficas, na anotação) $\left({ }^{75}\right)$.

- os graus dos advérbios e dos adjectivos (utilização do superlativo absoluto sintético em vez do grau normal): «Cristo marcou muito bem» é substituído por «Marcou Cristo muitíssimo bem» $\left({ }^{78}\right)$.

- a escolha dos verbos; exemplos: "Cristo disse (ditamou na anotação) aos seus apóstolos que aquele que exercesse autoridade se deveria considerar como um servidor dos demais» $\left({ }^{76}\right)$.

- a inversão de palavras na frase (hipérbato): Cristo marcou muito bem esse carácter de simples meio que compete à ideia de autoridade», é alterada para "Marcou Cristo muitíssimo bem esse [mesmo] carácter....» $\left({ }^{76}\right)$; repare-se também na interpolação do advérbio de inclusão mesmo, que reforça a ideia expressa por Cristo;

- a introdução de aspas para acentuar a demarcação do Libertário em relação à terminologia empregue pelo Estadista no seu discurso: é o caso de «republicano» (referido a regime (Texto.$^{\circ} 4$, p. 81):

- o distanciamento do locutor em relação ao seu enunciado, por exemplo, quando Sérgio afirma que o catolicismo como doutrina religiosa não «será da direita nem será da esquerda», e acrescenta: "Não quero dizer com isto porém (não se pretende dizer com isto, todavia, na anotação) que não haja doutrinas de carácter político com maior compatibilidade com a moral cristã....» $\left({ }^{77}\right)$.

— a interpolação de advérbios de modo, de afirmação etc.: «Admito uma governação dessa ordem.... como meio tran-

(i5) Ob. cit., p. 9.

$\begin{array}{lll}\left({ }^{76}\right) " & \text { (") } & \text { p. 21. } \\ (") & \text { pp. 12-13. }\end{array}$ 


\section{Antonio Sérgio}

sitório de democratizar mais [a fundo] uma democracia» $\left({ }^{78}\right)$; «À hegemonia do consumidor na vida económica [pois] corresponde à do cidadão na vida política» $\left({ }^{79}\right)$.

- a interpolação de nomes; é o caso seguinte: "O capital é necessário. Sê-lo-á sempre o [magnata] capitalista?» $\left({ }^{79}\right)$

- a interpolação de frases e de pequenos textos, como por exemplo a interrogativa em que se expressa a função fática «Percebes tu?» (vide Texto n. ${ }^{\circ} 2$, pp. 79-80) ou da afirmativa «Libertário sou eu, não são os comunistas» $\left({ }^{80}\right)$.

- anáforas (repetição de palavras ou expressões para as fazer ressaltar): a interpolação da preposição para no texto . $^{\circ} 17$ (p. 88) sobre os meios e os fins.

Apresentamos no Apêndice B, (pp. 77-78), uma listagem das ideias reforçadas, salientando desde já que dois aspectos foram fortemente realçados por Sérgio nas anotações: o antiestatismo, do qual decorre a necessidade de que os governantes se tornem dispensáveis, e a demarcação relativamente à linguagem de Salazar (o carácter «republicano» do Estado Novo, $\mathrm{o}$ «catolicismo» do Estadista, etc.).

\subsection{Atenuação de ideias}

Tal como procedeu para dar ênfase a certas ideias, para atenuar a intensidade de outras, Sérgio recorreu a múltiplos processos estilísticos, consoante os objectivos específicos das anotações e o contexto em que se encontram (trata-se de 25 casos, ou seja cerca de $5,8 \%$ do total).

Recenseamos as mais frequentes e significativas:

- a substituição, e interpolação de verbos não tão intensos, não tão taxativos como os da versão original; verifica-se portanto, uma modalização da atitude do sujeito perante o seu enunciado:

(") Ob. cit., p. 11.

C) $\gg "$ p. 29.

$\left.\mathrm{C}^{80}\right)$ " 


\begin{tabular}{|l|l|}
\hline VERSÃO ORIGINAL & \multicolumn{1}{|c|}{ VERSÃO REVISTA } \\
\hline /Há que/ distinguir & $\begin{array}{l}\text { «Cumpre/ distinguir, /ao que me } \\
\text { parecel, entre os que são absolu- } \\
\text { tos por acidente es que o são } \\
\text { por objectivo ou por sistema.» }\end{array}$ \\
/comparável/ & $\begin{array}{l}\text { «Entre a Convenção e um rei ab- } \\
\text { soluto, há diferença /que se pode } \\
\text { comparar/à que existe entre } \\
\text { quem mata um agressor em caso } \\
\text { de legitima defesa, quem mata } \\
\text { sistematicamente por ser ban- } \\
\text { dido.» }\end{array}$ \\
/creio/ & $\begin{array}{l}\text { «as virtudes fraternas» são «ab- } \\
\text { solutamente necessárias, /supo- } \\
\text { nho/ eu, para que viva normal- } \\
\text { mente um socialismo autêntico.» }\end{array}$ \\
\hline
\end{tabular}

- outros exemplos poderíamos citar ainda, mas limitamo-nos a referir o aparecimento de verbos como crer e parecer, na primeira pessoa do singular $\left.{ }^{82}\right)$, visando, igualmente, a atenuação de determinados juízos, eventualmente demasiado categóricos para o espírito cartesiano de Sérgio;

- a supressão de uma adjectivação por vezes excessiva e a escolha de adjectivos menos intensos: é o caso da supressão dos adjectivos desconfiada, exigente e fiscalizadora, que caracterizavam a atitude da "alma livre» face aos governantes (vide Apêndice D, Texto n. ${ }^{\circ}$ 9, pp. 83-84).

- a substituição e supressão de advérbios: «O 'sistema de ideias' do Evangelho é muito (também, na anotação) difícil de realizar» $\left({ }^{83}\right)$ (substituição do advérbio de modo muito, pelo de inclusão também); ou simples supressão de advérbios de tempo, como constante, constantemente etc.: "Assistência técnica e financeira constante a cada um dos casos particulares» $\left({ }^{84}\right)$.

- a substituição e supressão de frases e expressões de forte oposição às ideias do Estadista, por exemplo, quando o Libertário responde ao ataque que aquele faz às propostas de
C) Ob. cit., P- 26, p.
(") $>$ " 126.
(") $)$ " 7.
(") $)$ P. 42. 


\section{Antônio Sérgio}

renovação dos orgãos da Democracia, Sérgio substitui um comentário emotivo, relativo à ideia de que o sistema democrático estaria agonizante («Qual agonizante!»), por uma negação serena («Nem todos pretendem apenas isso» [prolongar o sistema democrático através de «medidas ridículas»]) (Texto.$^{\circ} 2$, p. 80), ou quando suprime a frase imperativa «Não prostituas a esse ponto a ideia de religião» (Texto n. ${ }^{\circ}$ 5, p. 82) e uma demarcação em relação ao comunismo «não desejo decerto o comunismo e sim propriamente o colectivismo» $\left.{ }^{85}\right)$.

- a supressão de pronomes pessoais, possessivos e indefinidos como nos seguintes casos: «No campo da economia, sou menos estadista do que tu (e nos outros menos ainda, evidentemente) (a maioria dos homens, na anotação): porque muitos dos serviços públicos que tu deixas (alguns deixam, na anotação) nas mãos do Estado, eu os entregaria de bom grado a régies cooperativas.» $\left({ }^{86}\right)$; ou na seguinte modificação de referente para o pronome possessivo: Disseram-te um dia que haviam atacado, sobretudo, o teu projecto de Constituição (projecto de Constituição do teu caudilho, na anotação) ${ }^{87}$ ); note-se que, com esta última variante, ao atribuir o projecto de Constituição não ao Estadista, mas ao seu caudilho, Sérgio introduz uma certa duplicidade na personagem do Estadista.

\subsection{Não repetição de palavras, ideias e sons}

Registámos 43 anotações (cerca de 10\% do total) que têm em vista estes três objectivos. Agrupá-mo-los, porque todos eles concorrem para depurar o texto, aliviando-o de palavras e expressões supérfluas, e/ou que prejudicam a sua sonoridade.

A transformação mais frequente (29 casos) é a supressão e substituição de um termo, ou termos, já expressos em frases anteriores. Evita-se, assim, a anáfora injustificada, a sobrecarga desnecessária do texto. Um exemplo: a supressão do vocábulo democracia na frase: «A democracia política e a democracia económica pressupõem-se reciprocamente, e as imperfeições da democracia política resultam em grande parte de não haver a democracia social» (Texto n. ${ }^{\circ} 1$ p. 79$)$.

Outra transformação que também se verifica, embora não tão amiúde (11 casos) é a supressão de frases, que con-

$$
\begin{array}{lccc}
\left({ }^{\mathrm{M}}\right) & \text { Ob. } & \text { cit, } & \text { p. } 34 . \\
(") & \prime & \text { " } & \text { p. 31. } \\
\left({ }^{81}\right) & " & \text { " } & \text { p. } 7 .
\end{array}
$$


têm ideias já expressas implícita ou explicitamente. É o caso do pleonasmo «libérrima liberdade» (Texto n. ${ }^{\circ} 17$, p. 88), em que se nota também um eco, e da supressão dos adjectivos moral e intelectual, referentes ao valor dos indivíduos (Texto n. ${ }^{\circ}$ 2, p. 80), ideia esta que é especificada mais à frente, em duas interpolações («respeito da dignidade humana» e «o amor da justiça»). Sérgio parece, neste último caso, querer evitar, para além da redundância, o chavão "valor moral e intelectual dos indivíduos».

Encontramos ainda outro exemplo, em que obsta a que dois sons iguais apareçam próximos (eco): unicamente e interiormente (Texto n. ${ }^{\circ}$ 9, p. 84).

Mas, por vezes, o pleonasmo e a repetição de palavras, são até convenientes, em passagens demasiado elípticas: «parece-lhe a ela uma vitória falhada, [uma vitória] inferior...» $\left({ }^{88}\right)$.

\section{Supressão de textos}

Embora a inclusão das anotações manuscritas torne a edição revista (1974), ligeiramente mais extensa do que a de 1933 (esta tem 143 páginas, em formato mais reduzido do que o das 84 páginas da edição das Obras Completas), registou-se a supressão de dois textos relativamente longos do discurso do Libertário.

No primeiro, esta personagem continuava a abordar a questão da autoridade e da obediência, o direito de crítica, os seus objectivos e o problema da autoridade absoluta, sem controlo. Note-se que algumas ideias já tinham sido expressas anteriormente (nomeadamente a do direito de criticar, fiscalizar e julgar a autoridade) (Texto.$^{\circ} 9$, pp. 83-84).

Esta supressão tinha sido antecedida por um longo acrescento, em que o Libertário faz uma advertência ao Estadista - «Não divinizes a entidade Estado conferindo-lhe a divindade dos antigos Reis - e exprime a sua opinião acerca do Estado e do cargo dos ministros (Texto n. ${ }^{\circ} 17$, p. 88).

O segundo texto suprimido, ou melhor, substituído, prosseguia a caracterização da ditadura de Mouzinho da Silveira e fazia uma distinção entre a «tirania dos bolchevistas e a tirania de Mussolini», expondo o Libertário as razões porque as rejeita a ambas (Texto n. $^{\circ} 10$, p. 84). A crítica que aí fazia aos «tiranos moscovitas», já era feita na intervenção

C) Ob. cit., p. 51. 
seguinte, daí que tenha sido substituída por uma interpolação em que, além das considerações sobre a ditadura de Mouzinho, aprecia a política agrícola dos governantes que se seguiram a este reformador, incluindo os do Estado Novo.

Com o desaparecimento desta passagem, deixa de figurar nos Diálogos o conceito de tirania, e o de tirano mantem-se apenas relativamente aos homens do regime de Salazar.

Noterse ainda, que, os dois textos suprimidos tinham sido previamente corrigidos por Sérgio (o primeiro tinha 8 anotações manuscritas e o segundo 3), que, num primeiro momento pensou recuperá-los. Mas a verdade é que, como assinalámos se tornavam extremamente redundantes (no primeiro, o termo autoridade era repetido nada mais do que nove vezes).

Outra passagem que desaparece, é a que faz referência às diversas Juntas que, de acordo com o programa cooperativista, trabalhariam em convergência com a Junta de Organização Cooperativa (a Junta de Reorganização Agrária, a Junta de Propulsão dos Estudos, a Junta de Educação Popular e a de Electrificação) (Texto n. $^{\circ} 12$, pp. 85-86). Trata $^{\wedge}$ -se de uma enumeração demasiado teórica e abstracta para produzir o esclarecimento do leitor.

\subsection{Simplificações e alterações formais}

As transformações a que chamamos, à falta de designação mais apropriada, «simplificações formais» (24 casos, 5,6\% do total), incluem elipses de certas palavras - nomes, verbos, pronomes, artigos, etc. - consideradas desnecessárias pelo autor (a nosso ver, é claro), para a compreensão do discurso, e variantes de carácter predominantemente formal - se é que assim as podemos denominar - que não alteram de um modo substancial o conteúdo das frases. Insistimos que não alteram substancialmente o conteúdo, pois estamos convictos de que, qualquer modificação no eixo sintagmático de uma frase, por mais reduzida que aparente ser do ponto de vista formal, resulta sempre numa alteração, ainda que muito ligeira do conteúdo.

Exemplo de uma elipse, é a supressão da expressão em itálico na seguinte frase: «o inglês na dose indispensável para os professores perceberem as obras que são escritas nessa língua» $\left({ }^{89}\right)$.

D Ob. cit., p. 47. 
Variante formal, é nomeadamente a substituição da locução concessiva se bem que, pela conjunção concessiva embora, verificando-se também uma substituição do verbo ter pelo verbo haver: «....não é o Estado o administrador da régie se bem que tenha (embora haja, na anotação) representantes Ideie] no seu conselho de administração»; ou a substituição do termo Renascença, por Renascimento $\left({ }^{90}\right)$.

Estas simplificações e alterações formais tornam o texto mais conciso, expurgando-o de partículas que o poderiam fazer excessivamente redundante. Contribuem igualmente para a sua clareza e correcção.

\subsection{Introdução de palavras car act eristic as da linguagem familiar}

São 20, as variantes ou acrescentos em que o principal objectivo foi, sem dúvida, o de tornar o diálogo entre as duas personagens mais vivo, mais realista e acessível ao leitor.

Trata-se, sobretudo, da introdução de novas formas de tratamento do Libertário para com o Estadista. O confronto das formas da versão original com as das anotações (escritas certamente em 1958), ainda que fora dos seus respectivos contextos, é concludente:

\begin{tabular}{|c|c|}
\hline VERSÃO ORIGINAL & VERSÃO REVISTA \\
\hline $\begin{array}{l}\text { caro Estadista } \\
\text { meu querido amigo } \\
\text { meu amigo } \\
\text { meu caro amigo } \\
\text { Estadista amigo } \\
\text { meu caro } \\
\text { Estadista } \\
\text { Estadista }\end{array}$ & $\begin{array}{l}\text { meu Manuel } \\
\text { Pois não Manuelzinho? } \\
\text { Manuelzinho } \\
\text { Manuelzinho } \\
\text { meu Miguelzinho (lapso do autor) } \\
\text { caro amigo } \\
\text { meu sobrinho (lapso) } \\
\text { meu caro Miguel }\left({ }^{91}\right)\end{array}$ \\
\hline
\end{tabular}

Verifica-se ainda a supressão de duas formas de tratamentos do original - «Meu caro Estadista» $\left({ }^{92}\right)$ - e a introdução do tratamento por tu em interpolações que, aliás, já tinha

O9b. cit., p. 32, p. 55.

$\left({ }^{\circ 1}\right) "$ " $"$ " p. 8, p. 9 , p. 13, p. 18, p. 29, p. 80 e p. 81. 
sido largamente utilizado na edição original. Exemplo: «Percebes tu?» (Texto n. ${ }^{\circ} 2$, pp. 79-80).

Nota-se a evolução de uma velha amizade (o tratamento por tu, no português, restringe-se às relações entre interlocutores numa determinada situação de igualdade, e de mais velhos para com mais novos), no sentido de uma maior intimidade. A relação entre as duas personagens, torna-se bastante mais próxima, como se, apesar das profundas divergências ideológicas e morais que separam o Libertário do Estadista, a afeição se fosse estreitando. Por outro lado, acentua-se também um certo paternalismo daquele para com este, que se prende com a profunda convicção de que os democratas são mais inteligentes do que os partidários do Estado Novo (Texto ${ }^{\circ} .^{\circ} 2$, p. 80) e com os aspectos do aristocratismo e do elitismo do pensamento sergiano.

Mas surgem outras características da linguagem familiar:

- os artigos definidos antecedendo os nomes de Maquiavelo, de Shelley e de Cristo, aproximando mais o emissor destas personalidades e das suas obras; Sérgio pretende assim, de algum modo, revelar a familiaridade e o profundo conhecimento que delas tem (lembre-se que na edição original, nomes como os de António Vieira e Gil Vicente, já eram antecedidos de artigo, enquanto outros, como Antero, Aristoteles, Augusto Comte, etc., permanecem desprovidos de artigo, o que parece revelar uma certa disparidade de critérios, por vezes pouco compreensível, na utilização dos artigos antes dos nomes próprios).

- inclusão de expressões coloquiais: «hoje em dia», «quem quer que transita» $\left({ }^{93}\right)$;

- substituição de expressões características do nível de linguagem cuidada, por expressões familiares: jornalista por nosso homem $\left({ }^{94}\right)$.

\subsection{Variantes características da linguagem cuidada}

Inesperadamente, registámos 5 casos em que se verifica o movimento inverso, ou seja, a colocação de dois verbos empregues em linguagem cuidada (transcorrer e observar), no lugar de dois outros, próprios de linguagem corrente (respectivamente passar e ver) $\left({ }^{95}\right)$; a variante por conseguinte (locução conclusiva) em vez da conjunção portanto $\left({ }^{96}\right)$; ou a

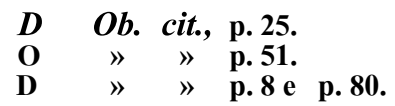


simples supressão de termos de linguagem familiar: «Mas voltemos ao nosso caso» $\left({ }^{97}\right.$ ) (em que se suprime o pronome possessivo nosso).

\subsection{Recurso à ironia ou ao humor}

Para além dos processos já inventariados, António Sérgio recorre por vezes a uma fina ironia, que perpassa em certos extractos, como o que a seguir transcrevemos, onde se encontra um surpreendente jogo de palavras:

«L. - ....Pois lá vai a história. Tinha-se instaurado, havia pouco, um governo excepcional nesse país, e era ministro das Finanças um certo brigadeiro e quartel-mestre, que nunca dera provas na especialidade, mas que gozava fama de competentíssimo. Chamava-se... Por sinal, não me recordo. recordes.

«E. - Adiante. Pouco importa que recordes ou que não

L. - Concordo.

E. - E pouco importa que concordes ou sem cordes» $\left({ }^{98}\right)$.

Como se vê, tratarse de um jogo entre o nome do ministro das Finanças Sinel de Cordes, e os verbos («recordes», «concordes»).

Nas anotações, introduzidas mais tarde, encontramos uma referência humorística a Quirino de Jesus, «0 Quirinal-Economista, esgrouviado e esguio» (") (na versão original, o Libertário referia-se ao "esguio Nacional-Economista»), e um comentário ao projecto de Salazar para o ensino (manter os professores diplomados nos centros urbanos e criar escolas nas aldeias, mantidas com «pequenas gratificações»): «Mas isso é um plano para a Idade Média (para os Afonsinhos, na anotação), meu querido amigo!» $\left({ }^{10 \circ}\right)$

\subsection{Actuálizações}

As 20 actualizações que detectámos, visam, como é óbvio, adequar certas referências bem datadas dos Diálogos, à nova conjuntura nacional e internacional dos finais dos anos 50 .

Para produzir o efeito desejado, Sérgio muda os tempos dos verbos (do Presente do Indicativo para o Pretérito Im-

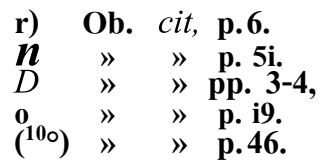


perfeito ou para o Pretérito Perfeito, no caso da alusão às acções de Mussolini $\left({ }^{101}\right)$, altera as referências temporais (por exemplo a que respeita à prática do cooperativismo, que tinha «quase um século de realizações» e que passa a ter, na anotação, «mais de um século») ( ${ }^{102}$ ), altera a terminologia demasiado referenciada ao período histórico de entre guerras (os «bolchevistas», passam a ser designados por «homens soviéticos») ${ }^{103}$ ) e o exemplo de um católico de esquerda (substituição do exemplo dos irmãos Alves Correia, pelo do bispo do Porto) $\left({ }^{104}\right)$.

\subsection{Lapsos}

Já referidos atrás, os quatro lapsos em que o autor incorreu, constituem um campo privilegiado para nos apercebermos do cuidado e da atenção com que se empenhou na revisão dos Diálogos. Mas podem, além disso, deixar transparecer um certo cepticismo de Sérgio, relativamente à possibilidade de publicação do livro. Nã̃o esqueçamos, que, tanto em 1945, como em 1958, passados efémeros períodos de esperança na abertura do regime, a acção da censura e a repressão às actividades políticas da oposição voltaram a intensif icar-se rapidamente, quebrando as últimas ilusões dos homens da oposição. $O$ desvanecimento dessas ilusões acerca de uma hipotética liberalização do regime, poderá ter sido aqui, a causa do abrandamento da vigilância do ensaísta no seu paciente trabalho de refundição da obra. E aliás sintomático, que, dos quatro lapsos recenseados, dois se encontrem nos Diálogos Quinto e Sexto, (que são também os menos corrigidos, ambos têm apenas 29 anotações, $6,7 \%$ do total), um no Apêndice final, e o outro no Diálogo Primeiro.

\subsection{Correç̧̃es cuja versão original é ilegível ou oferece dúvidas; \\ frases escritas ao alto das páginas}

Ao longo da leitura das notas da edição crítica dos Diálogos (1974), encontram-se 9 alterações manuscritas que substituem versões originais ilegíveis (6 casos), ou que ofereceram dúvidas aos seus organizadores.

Há ainda duas frases que Sérgio escreveu ao alto de duas páginas, sem indicação do local onde deveriam figurar.

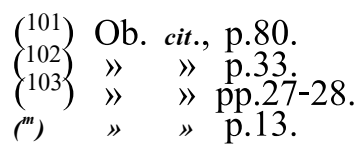


Uma delas está incompleta, e tem uma palavra ilegível $(« \mathrm{O}$ regime que parece para ti o ideal é o do capitalismo de monopólio. Pelo menos, é para... um capitalismo de monopólio que parece sobretudo...») $\left({ }^{105}\right)$; a outra, constitui um reforço, em que o Libertário vinca bem o acto de servir: «Servir - percebes tu? Não te esqueças do Evangelho de S. Lucas, no capítulo 22 que te citei há pouco» $\left({ }^{10 \mathrm{G}}\right)$.

\section{NOTAS FINAIS}

Nos Diálogos de Doutrina Democrática, exprime-se de uma forma magistral, o carácter «visceralmente polémico» $\left({ }^{107}\right)$ do ensaísmo sergiano, a elegância e o brilhantismo com que desmonta o discurso ideológico e político de Salazar.

De entre as obras e artigos de António Sérgio elaborados até 1933, os Diálogos constituem não só uma obra de circunstância, uma réplica ao mentor do Estado Novo, mas acabam por ser de algum modo também, uma obra de síntese da produção teórica que vinha desenvolvendo.

Por outro lado, é a primeira, em que expõe largamente o programa cooperativista e um plano de reforma agrária. Foi no seu exílio de quase seis anos em França, que Sérgio teve oportunidade de estudar a fundo os teóricos cooperativistas franceses - Charles Gide, Ernest Poisson e outros. Lembre-se que, desde Março de 1932, Sérgio vinha publicando na Seara Nova artigos destes autores, com pequenas anotações críticas.

Sendo um livro de carácter essencialmente pedagógico e didáctico, escrito no momento em que o Estado Novo montava os seus aparelhos políticos e ideológicos, os Diálogos mantiveram a sua actualidade durante a imobilista ditadura de Salazar, razão por que o autor pensou publicá-los aquando das eleições para a Assembleia Nacional em 1945, e do lançamento da candidatura de Humberto Delgado à presidência, alturas em que poderiam ter atingido um público mais vasto.

$E$ aqui, levanta-se a questão de saber a que camadas da população se dirige o livro. Apesar de ele ser, no conjunto

(i5) ob. cit., p. 31; esta frase deveria ser incluída algures quando o Libertário critica a política económica do Estadista.

${ }^{(106)}$ Esta anotação deveria inserir-se algures no Texto n. ${ }^{\circ} 17$ (p. 88) a proprósito do exemplo do polícia de trânsito.

crise da ideologia burguesa, Lisboa, Seara Nova, 1964, p. 130. 
da obra do ensaísta dos mais acessíveis, não temos dúvidas que os Diálogos foram produzidos para as elites, essas elites que, segundo Sérgio, eram em Portugal muito reduzidas. Atestam-no, entre outras referências, as numerosas citações de outros autores, em latim, italiano, inglês e francês, que não são traduzidas.

Se pensarmos que em 1930, o analfabetismo ainda atingia quase $70 \%$ da população $\left({ }^{108}\right)$, e que só uma ínfima minoria tinha acesso aos escassos liceus então existentes nas nossas cidades, acabaremos por nos aperceber da insignificância, na sociedade portuguesa, do número dos que estariam em condições de compreender a mensagem de Sérgio.

Terá sido a consciência desta situação de isolamento que o levou a introduzir, com alguma frequência, (na edição original e sobretudo nas anotações), palavras e frases características da linguagem familiar e da linguagem corrente, conciliando-as harmoniosamente com outros níveis (termos abstractos próprios do texto filosófico, termos literários e técnicos).

Nota-se pois, uma evolução no sentido de tornar a obra mais acessível ao leitor, evolução também perceptível, como vimos, no recurso frequente a exemplos concretos que «ilustram» as preposições teóricas, nas comparações expressivas, na constante preocupação em definir mais exactamente as ideias, tomando-as mais explícitas, precisas e claras (mais de $40 \%$ das anotações correspondem a tal objectivo).

Pode-se mesmo dizer, que esta terá sido a grande preocupação de Sérgio, quando corrigiu a edição primitiva.

Preocupação que se prende com um certo perfeccionismo, na luta pela expressão exacta, pelo constante apuramento estilístico, pela simplicidade e transparência das palavras.

Mas a simplicidade de expressão em Sérgio, corresponde geralmente a uma grande riqueza no conteúdo, por vezes a uma complexidade de ideias, que tende a limitar bastante a inteligibilidade da sua escrita (releiam-se certas passagens de carácter filosófico, nas quais o recurso frequente a conceitos altamente abstractos e a termos científicos especializados, dificulta a sua compreensão pelo leitor comum).

Se de uma maneira geral a utilização dos vários níveis de linguagem - literário, cuidado, corrente, familiar e popular - se harmoniza num equilíbrio sóbrio, clássico, dir-se-ia, no entanto, que nem sempre os propósitos do pedagogo pre-

$C^{08}$ ) Vide Dicionário de História de Portugal, Vol. II, Lisboa, Iniciativas Editoriais, 1965, p. 53. 
valecem sobre as exigências do filósofo, sobre as particularidades da sua linguagem e as referências que apontámos.

Constatou-se, por outro lado, uma certa preocupação por parte do ensaísta em evitar a redundância e a repetição de palavras, em tornar alguns textos mais concisos, mais elípticos (um exemplo é a intervenção do Libertário em que se refere ao feminismo, tema marginal nos Diálogos) $\left({ }^{109}\right)$.

Este tipo de transformações, bem como a atenuação da intensidade de ideias, recorrendo frequentemente a supressões, contribuem para tornar o texto mais condensado e penetrante, apesar de relativamente mais longo do que o da edição original.

No que respeita ao programa cooperativista, transparece das anotações introduzidas, uma definição mais nítida do modo como deveria ser aplicado, nomeadamente no domínio da agricultura, em que restringe as transformações ao grande capitalismo agrário.

Da análise feita, concluímos ainda que, cerca de vinte e cinco anos depois da primeira tentativa de publicação, as ideias se tornam mais amadurecidas, menos dependentes do sentimento e da emoção de um Sérgio que acabara de regressar das agruras do exílio, para encontrar os destinos de Portugal já entregues a um obscuro professor catedrático da Universidade de Coimbra.

Este amadurecimento de ideias, verifica-se ainda na utilização de um aparelho conceptual mais rigoroso, de uma terminologia actualizada.

Ao terminarmos, fica-nos a impressão de que no seu apostolado cívico, no constante debate de ideias, o grande ensaísta que foi António Sérgio vivia permanentemente ocupado, em melhorar a sociedade portuguesa, em aperfeiçoar-se através do método racionalista de auto-disciplina crítica.

$\left({ }^{109}\right)$ Diálogos..., p. 51. 


\footnotetext{
Moral Democrática

- queremos que cada um vá convencido e muito consciente do caminho que segue;

* tomar os outros como pessoas

* tratar o próximo como um fim

-Democracia: sistema em que se deseja para os homens o máximo possível de consciência;

- Ideal de

veracidade

respeito absoluto pelo intelecto alheio

- Verdadeira sociedade:

* sociedade do espírito

* perfeita transparência de intelecto a intelecto, entre alma e alma;
}

— queremos esforçar-nos [os democratas] por ser justos, sabendo que muitas vezes o não somos;

- quando foi injusto na sua política o democrata verdadeiro reconhece que o foi;

- o ideal democrático é

* exigente, está acima de nós democratas
Jesuitismo / Maquiavelismo

conduzir os homens sem que se apercebam do que estão fazendo é

* atitude do desprezo máximo

* tomar os outros como meras cousas

* tratar o próximo como simples meio;

- mentir é * perder a própria * alma * desprezar a alma a quem mentimos * empeçonhar toda $a$ fonte interior da sociabilidade humana

- democrata que não é verídico que não é sincero que trata os outros como se fossem cousas

indivíduo infiel à sua própria ideia

* erige em ideal o seu próprio erro

* tenta justificar o erro com maquiavelismo

* democrata maquiavélico: democrata falso

- no maquiavelismo, a própria doutrina inferioriza o homem; 
Moral Democrática

* é como o ditame de Cristo: «sede perfeitos como o vosso Pai do Céu é perfeito.»
- o democrata quer que se respeite invariavelmente 0 que dita a Razão a cada um de nós.

- obediência sensível, quando necessária, jamais a obediência do espírito, a limitação do nosso juízo próprio, quando iluminado pela luz racional;

— Nunca mentir. Nem a nós nem aos outros;

- interesse moral de manter a ideia do respeito às normas;
Jesuitismo / Maquiavelismo

* o próprio ideal é de queda de abaixamento de corrupção de sacrifício da ordem invisível da al$m a$ à sociabilidade aparente e a disciplina sensível

* o maquiavélico destrói a sociabilidade intrínseca e do espirito a uma ordem que é só material;

- falso democrata que se faz insincero: homem infiel a uma doutrina boa; mau democrata;

- tirano que procede maquiavelicamente: homem fiel a uma doutrina péssima;

- ser jesuíta é sacrificar a verdade intrínseca do espirito a uma mera conformidade de natureza material;

- exemplo de S. Francisco Xavier:

* confissões de fé puramente verbais, inconscientes;

* sacrifício da veracidade à aparência sensível, do espirito religioso à pura letra;

de Nobili: exemplo do jesuíta Roberto

* profunda perversão da mente;

* sacrifício moral do indivíduo a uma ideia absurda e imensamente imoral;

* infinito da exaltação da aparência;

* o mais ousado, maquiavélico, delirante sacrifício da veracidade do espírito ao puro formalismo da palavra vácua, do efeito sensível;

- exemplo de um punhal com a forma exterior de um crucifixo: 
Moral Democrática

respeito às normas, aos obstáculos individuais é a própria alma de uma sociedade qualquer,

respeito à lei buscada pela Razão e legitimamente promulgada;

* para o moralista, a sedução de passar por cima de tudo é loucura;

* para o verdadeiro moralista cristão, é o máximo triunfo do diabólico;

- a Democracia no aspecto moral é a vontade de resistir às monstruosidades do mando;

- o poder corrompe;

- o espírito é incompatível com o menor poder;

- o homem que exerce o poder político só deve trabalhar por se tornar dispensável;

- nós partimos de princípios morais, dos mais puros ditames do Cristianismo;

- para não cairmos em tais loucuras . [o lucro e o mando], preferimos a abstinência;
Jesuitismo / Maquiavelismo

* a religião exterior e o mal interior;

* a política a destruir a ética;

* a ordem aparente a corromper 0 espírito, a coerência íntima;

* a verdade sacrificada a um efeito sensível;

- aberração jesuítica:

* vício de pôr a matéria acima do espirito; as cousas acima da alma;

* afogar a moral na conveniência política;

* sacrificar a uma ordenação coisista, material, visível, a ordenação intrínseca da consciência;

* ideia de passar por cima de tudo, (ideia que seduz os mandões),

de todas as leis de todas as normas de todos os obstáculos individuais

— os ilustres maquiavélicos partem de necessidades políticas;

- o lucro desmoraliza os homens; é um vinho que embriaga os homens; 
Moral Democrática

_ protestamos contra o capitalismo;

- a vida moral exige:

* a liberdade do trabalhador

* a sua participação na direccão da vida económica

* a supressão do objectivo do lucro

— pretendemos suprimir o vício; lutamos pela liberdade;

— não admitimos virtudes na alma de um escravo;

- fraternidade humana e universal;

- a Democracia tem o carácter de uma religião;

- a nossa moral vem da revelação da consciência;

- aplicamos uma regra moral a situações diversas, e com esta diversidade se vai progredindo;
Jesuitismo / Maquiavelismo

- o mando é outro vinho que embriaga também, tentando-os a passar por cima de tudo: de todas as normas, de todas as leis, de todos os obstáculos individuais;

- debatem-se na ideia de organizar o vício, só possível pelo maquiavelismo;

—espírito capitalista

- espírito corporativo, espírito exclusivista;

-o maquiavelismo é uma habilidade política;

— a detenção do mando justifica tudo e transforma os maiores vícios em virtudes;

- vence-se pela maldade e pela mentira;

\section{APÊNDICE B}

\section{Inventário das ideias e aspectos teóricos reforçados}

a não necessidade de modificar o «sistema das ideiis» democráticas (p. 6).

- a eternidade do «ideal democrático» (p. 8)

- a democratização da democracia por meio de uma governação excepcional (p. 11)

- «o carácter de simples meio que compete à ideia de autoridade marcado por Cristo») (p. 21)

- a violência do Estadista e dos homens soviéticos (p. 27)

- a demarcação em relação aos comunistas, classificando-se como Libertário (p. 27)

- o autoritarismo e o estatismo do Estadista (p. 28)

- o dever do homem de autoridade em se tornar dispensável (p. 22)

- a oposição à atitude de desprezo do Estadista para com os homens (p. 24) 
o propósito do Estadista de só querer «fazer homens de iniciativa... económica» (p. 31)

- a demarcação em relação ao discurso de Salazar (p. 11, p. 22, p. 42 e p. 46$)$

- _ a oposição aos adversários da liberdade (p. 22)

- a oposição em relação à «civilização que existiu até hoje» (p. 31)

- o racionalismo (p. 56)

- o êxito da prática da cooperativa (p. 33)

- a necessidade da intervenção do lavrador na «cousa pública» (p. 47)

- a necessidade da actualização dos professores (p. 47)

- a actuação dos reformadores «para remédio de males individuais»» (p. 59)

- a correspondência do «voto individual e democrático» com o «voto individual dos consumidores nas cooperativas» (p. 78)

\section{APÊNDICE C}

\section{Ideias atenuadas}

a dificuldade de realização do «sistema de ideias» do Evangelho (p. 7) a oposição em relação à crítica que o Estadista faz às reformas politicas propostas pelos democratas (p. 8)

- a oposição em relação ao Estadista (p. 7, p. 13, p. 18, p. 31 e p. 52) a demarcação em relação aos dirigentes soviéticos e ao Estadista (p. 27)

- a demarcação em relação ao comunismo por oposição ao colectivismo (p. 34)

a intensidade da atitude critica perante os governantes (p. 24 e p. 26)

- o carăcter constante do exame feito pelos contabilistas ao serviço do Ministério da Cooperação à escrituração das cooperativas (p. 33) o carácter constante da assistência técnica e financeira a cada um

- dos casos particulares» na reforma agrária (p. 42)

a possibilidade de a democracia cooperativa poder ser desenvolvida imediatamente dentro da sociedade capitalista (p. 34)

a acção de impor e condicionar aos colonos o projecto cooperativista (p. 39 e p. 41)

— a necessidade de modificação dos programas das escolas normais (p. 47) 


\section{APÊNDICE D}

Edição original
$(1933)$

Texto $n .^{\circ} 1$
Textos da edição revista

(1945? / 1958?)
Objectivo das transformações

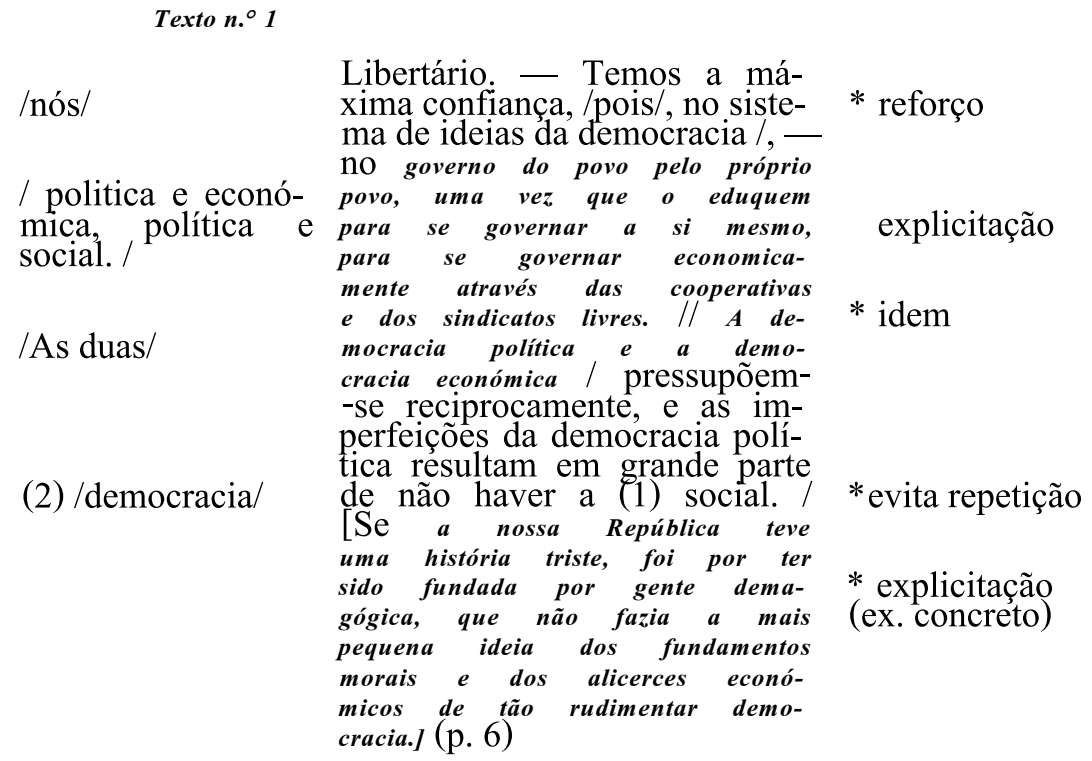

Texto $n .^{\circ} 2$

/Porque teimas tu/ /querer/

/era possível dentro do/

/passou/

/eterno da democracia: a/

(2) sublinhados do autor
L _ [Posto isto] por que [é que] teimas em não/ quereres/perceber que os democratas pensem a mesma cousa dọs velhos meios da democracia? IEntre nós], esses velhos orgãos da democracia tiveram a forma que /se julgou adequada no/ momento político que /transcorreu/. E pretendemos agora renová-los, de acordo com as lições da experiência, para uma maior aproximação do ideal/ / democrático, que é de facto eterno: o da/ igual dignidade para todos os homens.

A razão indica os fins (2) supremos, de uma vẹz para sempre: a experiência, pouco a pouco, aperfeiçoa os meios (2)

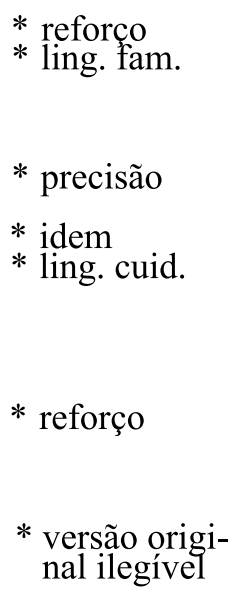


Edição original

(1933)

/Qual agonizante!/

/caro Estadista/

(3) /moral e intelectual daqueles/

loutra/
Textos da edição revista

(1945? / 1958?)
Objectivo das transformações
[Percebes tu?]

Estadista. - «Mas que propõem eles, afinal, para que se efective essa renovação? Medidas ridículas, que se não adaptam ao próprio sistema: ligeiras alterações no regimento interno das Câmaras, limitações no tempo dos discursos, restrições no uso da palavra, etc., etc. Paliativos ingénuos que não resolvem nada, que pretendem, apenas, prolongar a pobre vida de um sistema agonizante...»

L. - $/$ Nem todos pretendem apenas isso./ O que faz o futuro dos sistemas, 7 meu Manuel/, é o valor (3) dos indivíduos que o defendem. Mede esses valores num campo e noutro, em Portugal. Não é só a «mística» democrática, como tu dizes: é a inteligência democrática que se manifesta superior à /dos fascistas/. [E o seu respeito da dignidade humana.] Olha para a mocidade, e dize-me onde está a inteligência, não os embelecos de talentinho, mas a verdadeira inteligência [e o amor da justiça]... Ouve: que pensas tu das revoluções?

(p. 8)

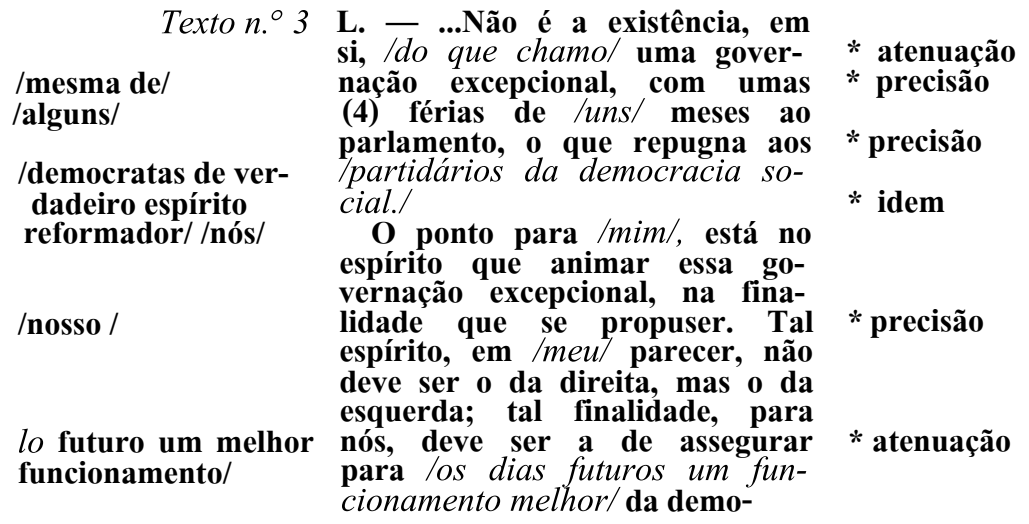


Edição original (1933)

\section{/Admitimos uma governação excepcional/}

Texto $n^{\circ}$

\section{/republicano/}

(5) /progressiva/
Textos da edição revista

(19457 / 1958?)
Objectivo das transformações cracia politica, e lançar as bases criadoras da democracia social, sem a qual a democracia politica estará sempre em perigo de se perverter. [E lançá-las, como? Fomentando as cooperativas de consumo e as cooperativas de lavradores para transacções em comum, para crédito mútuo.] Admito uma governação dessa ordem/, em suma, como meio transitório de democratizar mais [a fundo] uma democracia.

(p. 11)

\section{* precisão}

* reforço

E. - Pois para mim «o problema é este: de um lado, uma necessidade urgente, orgânica, nacional, de governar para a direita e com a direita. Do outro lado, uma verdadeira mística republicana. Mas não considero essa marcha para a direita como incompatível com o regime republicano...»

L. - Regime / «republicano»/ * reforço sem liberdade, sem democratização progressiva da vida pública, do crédito, da economia, da educação; sem fiscalização do governo pelo povo; sem possibilidade de criticar a autoridade; regime/《republicano»/ sem marcha (5) para a esquerda, numa palavra, - não o considero eu como republicano. [Para mim pouco se me dá de uma República que não trate da elevação dos homens pobres, que não caminhe todos os dias para uma maior justiça social.] E tu? A que chamas «regime republicano»? A que chamas tu «marchar para a direita»? (p. 11)

* idem; aten.

* reforço 
Edição original

(1933)

Texto $n .^{\circ} 5 \quad$ L. - ...Se a maioria dos católicos dos países latinos seguem a política da direita, nã̃o fazem por motivos religiosos: fazem-no sim por conveniên-

/exteriores/

(6) [não prostituas a esse ponto a ideia de religião./

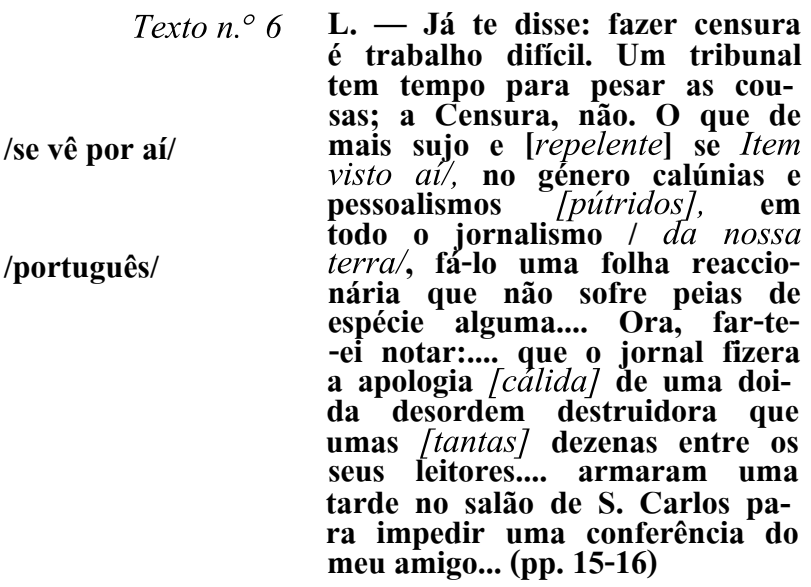

Texto $n .^{\circ} 6 \quad$ L. - Já te disse: fazer censura cias /plutocráticas/ e materiais, ligião verdadeira, da pura doutrina do Evangelho. Fazem-no tão-só como homens ricos, ou então como adictos ao capitalismo e não como religiosos. (6) No espírito desses maus católicos, a religião é um «freio» para subjugar o povo: é um simples antemural dos seus interesses [e dos interesses do capitalismo, a que estão ligados. Hoje do capitalismo de monopólio, de que o corporativismo de Estado é um instrumento.] (p. 13)
Objectivo das transformações
* precisão

* atenuação

* explicitação

$$
\begin{aligned}
& \text { * reforço } \\
& \text { * actualização } \\
& \text { * reforço } \\
& \text { * ling. fam. } \\
& \text { * reforço } \\
& \text { * idem }
\end{aligned}
$$


Edição original

(1933)
Textos da ediç̃o revista

(1945? / 1958?)
Objectivo das transformações

\begin{abstract}
Texto $n .^{\circ} 7$ L. - ...Mas espera: vejo na cancela o teu amigo, /Quirinallo esguio Nacionai - -Economista esgrouviado e es-
-Economista/ -Economista/

/ao vosso trabalho/ reformas para o Diário do Governo. Deixo-vos là vossa faina/. Continuaremos amanhã. [E entretanto, pensa nisto: vai trabalhando por te tornares dispensável. Assim faço eu.] (p. 19)
\end{abstract}

Texto $n .^{\circ} 8 \quad$ L. $\quad$ - ...E que veio o Cristo fazer ao mundo? Pôr em liberdade os oprimidos, [pregar aos cativos remissão, evangelizar especialmente a gente pobre. Vós, pelo contrário, sacrificais os pobres aos negocistas, tornais mais míseros os que já eram míseros, tornais mais ricos os que já eram ricos e actuais como se o vosso objectivo fosse reduzir-nos todos à escravidão.]

/Essa/ /Libertar/, por excelência, é que é a verdadeira missão divina. Entre os fins do enviado de Deus, vemos que a autoridade jamais figura: todos eles pelo contrário, se apresentam como fins de libertação. [A função do homem de autoridade deve ser trabalhar por se tornar dispensável, e aos que se apegam ao gosto de exercer o seu tenho-os eu na conta de desequilibrados mentais.] (p. 22)

$$
\begin{aligned}
& \text { * ironia } \\
& \text { * reforço } \\
& \text { * reforço }
\end{aligned}
$$

* reforço

* reforço

\section{Texto $n .{ }^{\circ} 9$}

/do homem/

(7) /um homem público/

(8) /um político/
L. - ...Regra absoluta /da al$\mathrm{ma}$ livre: nunca aclamar um (7) /senhor/ governante, (8) seja esta liberal ou não o seja; por maioria de razão, nunca ser tímido diante dele, não sentir por ele «instintivo res-
* precisão

* precisões 
Edição original

(1933)

(9) /sempre/

(10)/desconfiada, exigente, fiscalizadora/

/unicamente/
Textos da edição revista

(1945?/1958?)
Objectivo das transformações peito», ou «temor aflitivo» ante o seu contacto: [mas] conservar (9) uma atitude [desprendida,] critica, (10) ainda que concordemos com a sua obra, ainda que o ajudemos na sua acção. As almas libertas, as bem nascidas, - /só/ se comovem e interiormente se inclinam ante as puras grandezas espirituais, quando desacompanhadas de qualquer poder.

(p. 24)
Texto $n .^{\circ} 10 \quad$ L. - ...̀̀ ditadura de Mouzinho da Silveira chamo eu uma ditadura liberal, porque tinha finalidade liberal, porque consistiu num meio transitório de

/nos dar/ /nós não tinhamos/; /Foi uma ditadura passageira, e, em suma, antiabsolutista. Há que distinguir, também, entre a tirania dos bolchevistas e a tirania de Mussolini, apesar de que as rejeitamos a ambas elas: porque aos tiranos moscovitas os anima um ideal emancipa dor, se bem que, em meu entender, eles não considerem suficientemente que os meios empregados para atingir um fim devem ter sempre homogeneidade moral com os próprios fins a que se quiser visar.f /criar/ liberdades que /não havia/ /,arrancando os homens dos nossos campos ao parasitismo do clero e dos aristocratas. Mas os governantes sobrevindos, por desgraça, desfizeram a obra social do Mouzinho, com enorme prejuízo do sector agrícola, hoje sacrificado em maior grau do que nunca. Tu e os teus amigos reduzistes o agrícola à maior miséria, tudo em benefício dos senhores plutocratas, sustentáculos e aproveitadores do Estado Novo/, (p. 27)

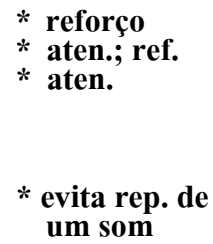

* precisão

* explicitação

$$
\begin{array}{rl}
\text { Texto } .^{\circ} 11 & \mathbf{L} \text { - ... [Vens sempre com o * reforço } \\
& \text { interesse do Estado. A mim só } \\
& \text { me importa o interesse do Po- } \\
& \text { vo, consumidor dos serviços }
\end{array}
$$


Edição original

(1933)

(11) / D e i x e m os para a ma nh ã a questão agrária. Queres? - [E.B. Pois sim. [D. - $\mathbf{E}$ tratemos agora dos outros casos.»//

/ora/

/bolchevistas/

/na pouca repugnância pela violência/ /nenhuma/

/creio/

/Suponho/ /comunismo/

(12)/que buscamos atingir/ /bolchevistas/

/Levaria, se o Estado a não ajudasse; mas eu quero que o Estado a auxilie./
Textos da edição revista (1945? / 1958?)
Objectivo das transformações que the são fornecidos através dos servidores que constituem $o$ Estado.] Tu é que confundes, meu caro Estadista...

(11) Confundes o comunismo, ai, com as ideias libertárias. Sabes decerto que são cousas diferentes, mas esqueceste-o... [Libertário sou eu, não são os comunistas; ] /e/, em três pontos, pelo menos, estás tu pertíssimo dos /homens soviéticos/; e estou eu longissimo. A saber: [(!)] na predilecção por um Estado forte [,quer dizer, pela $t i$ rania dos magnates do Estado]; [(2)] /no emprego sistemático da violência/; [(3)] na /poucal consideração, enfim, pela liberdade individual, no campo moral, jurídico e politico... O emprego da violência, por outro lado, contraria o surto das virtudes fraternas, - absolutamente necessárias, /suponho/ eu, para que viva normalmente um /socialismo/ autêntico. /Julgo/ que os meios a empregar [na obra] devem ser da natureza dos fins (12). Para fins fraternos, meios fraternos $[\mathrm{com}$ sentimentos constantes do amor ao próximo]. A favor dos /soviéticos/, bem sei, podem alegar-se circunstâncias de facto: a necessidade de defenderem a sua obra contra os Estados [dominados pelos] capitalistas, etc., etc.

(pp. 27-28)
Texto $\mathbf{n} .^{\circ} 12$

E. - Essa socialização pelo cooperativismo, como tu preconizas, levaria séculos!

L. - ... [Não sei porquê. Questão de vontade. E sobretudo se o Estado ajudar, sem se meter a criar e a mandar. O povo fará tudo por si.] Não desejo que o próprio Estado socialize os meios de produção e de troca, que administre ele próprio

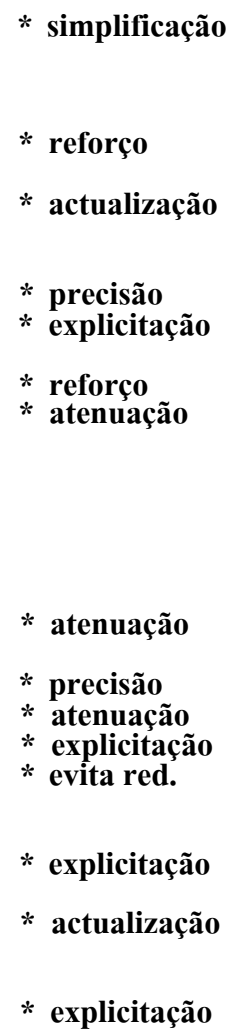


Edição original

(1933)

(13) /constantemente/ /transformar em/ /sempre (ou quanto possível), organizando a produção das cousas dentro duma cooperativa de consumo. Essa Junta de Organização Cooperativa tra. balharia de comum acordo com uma Junta de Reorganização Agrária, com uma Junta de Propulsão dos Estudos, com uma Junta de Educação Popular, com uma Junta de Electrificação./

\section{Texto $n .^{\circ} 13$}

Textos da edição revista

(1945?/ 1958?)

qualquer empresa; desejo que auxilie os cidadãos [do País] a socializarem [a economia] pelas cooperativas. Eu criaria, se fosse estadista, um Ministério da Cooperação, ou uma Junta de Organização Cooperativa [,ou uma Directoria Geral do Cooperativismo no Ministério do Trabalho e dos Seguros Sociais]. O Ministério da Cooperação contrataria técnicos competentes da administração cooperativa; manteria um corpo de contabilistas (funcionários do Estado como quaisquer outros) que examinassem (13) a escrituração das cooperativas, e que relatassem aos sócios e ao próprio Estado; e teria uma verba para expropriar empresas, mediante a justa indemnização, afim de as lentregar às/ cooperativas. Mas /deixando organizar a produção dos bens pela Federação das Cooperativas de Consumo. Quanto a ti, - trabalha por te tornares dispensável./ (p.33)
Objectivo das transformações
* explicitação

$$
\text { * atenuação }
$$

* precisão

* simplificação
L. - ...A Democracia Cooperativa, pois, tem como ponto de partida o actual regime do capitalismo, e coloca-se no campo da competência económica com o actual comércio capitalista. Cria a Sociedade Nova, desde já, dentro da velha. Substitui, em primeiro lugar, o comércio privado de retalho; depois, o comércio por grosso; 
Edição original

/interior/

/exterior/

/consciência/

/externa/

/interior/
Textos da edição revista (1945?/ 1958?)
Objectivo das transformações depois (produzindo para si), suplanta o capitalismo industrial; depois, o financeiro; finalmente, o [grande] capitalismo agrário [ mas mantendo os pequenos e médios proprietários, tigados em cooperativas locais de crédito e sólidas cooperativas de transacções em comum].

(p. 35)

Texto $n .^{\circ} 14$ L. - ...O ideal democrático é exigente; está acima de nós. $[E$ como o ditame de Jesus Cristo: "Sede perfeitos, como o vosso Pai do Céu é perfeito.»] No maquiavelismo, pelo contrário, é a própria doutrina que inferioriza o homem, é o próprio ideal que é um ideal de queda, de abaixamento, de corrupção, de sacrificio da ordem /invisível/ da alma à sociabilidade aparente e à disciplina/sensível/.

(p. 53)

Texto $n .^{\circ} 15$ L. - ...O democrata, pelo contrário, quer que se respeite invariavelmente - e que se siga quanto for possivel, - o que dita a /Razao/ a cada um de nós [, a lei da consciência dessubjectivada]. A obediência /sensível/ quando for necessária, jamais porém a obediência /do espírito/, jamais a limitação do nosso juizo [próprio, quando iluminado pela luz racional. Nunca mentir. Nem aos outros, nem a nós].

(p. 56)
* precisão

* idem

$$
\begin{aligned}
& \text { * precisão } \\
& \text { * idem }
\end{aligned}
$$

$$
\begin{aligned}
& \text { * precisão } \\
& \text { * idem } \\
& \text { * reforço }
\end{aligned}
$$

Texto $n^{\circ} 16$ L. - ...e a Democracia, no aspecto moral, é a vontade de resistir às monstruosidades do mando [. O poder corrompe; o espírito é incompatível com o menor poder. O homem que exerce o poder político só deve * reforço trabalhar para se tornar dispensável]... Mas agora reparo: 
Edição original

\section{Texto $n .{ }^{\circ} 17$}

(14) /ali/

fo alcance do ponto/

dibérrima/
Textos da edição revista

(1945?/1958?)
Objective das

transformações esquecemo-nos, ao que parece, do nosso ponto de partida: a questão feminista...» (p. 57)

L. - ...O agente de polícia que regulariza o trânsito não age para me impedir de eu ir [para] onde quero. Actua (14), pelo contrário, para me facilitar la realização do percurso/ que eu quero, com o menor perigo material possível. Eu vou [para] onde quero, por um modo que o polícia me torna fácil. A sua função, por consequência, é ajudar-me a atingir com o menor risco físico o sítio a que livremente me propus chegar. É um servidor, por consequência, da minha /plenissima/ liberdade de escolha. Pois que a liberdade está no fim a que eu miro, e não nas condições físicas dos respectives meios. Ele serve o meu fim - o meu livre fim - proporcionando-me os meios de segurança máxima. Ele não condiciona a finalidade que eu viso; pelo contrário: a finalidade livre de quem [quer que] transita é que condiciona os actos do polícia das ruas. $O$ polícia, portanto, é ali um servo da liberdade do povo, assim como um governo deverá sê-lo também. [Não divinizes a entidade Estado, conferindo-lhe a divindade dos antigos reis. $O$ Estado não passa, para um homem de hoje, de um conjunto orgânico de serviços públicos, de que os livres cidadãos são os usurários. Os ministros são dirigentes desses serviços, eleitos pelos cidadãos consumidores e sujeitos à crítica dos consumidores. Não têm nada de divino, e são menos inteligentes, muitas vezes, do que a média dos consumidores a que eles deverão servir.] Não me repugna, como estás vendo, a existểncia da autoridade, (p. 25)
* reforço

* precisão

* evita redund.

* reforço

* evita

pleonasmo

\section{* linguagem familiar}

* reforço 


\section{Os diálogos de doutrina democrática}

\section{APÊNDICE E}

\section{Interpolação de textos}

Tem algum interesse conhecer os temas abordados nos pequenos textos acrescentados à versão original. Recensearam-se na ordem em que se encontram na obra:

- definição de democracia (p. 6)

- a l. ${ }^{\mathrm{a}}$ República portuguesa (razoes porque «teve uma história triste») (p. 6)

— as condições «muito severas» para a aprovação de votos de desconfiança ao governo (p. 10)

- o modo como se deve lançar «as bases criadoras da democracia social»: o fomento das cooperativas (p. 11)

- o emissor demarca-se «de uma República que não trate da elevação dos homens pobres...» (p. 11)

— os interesses que representa a religião para os «maus católicos» (p. 13)

- a actuação dos tribunais (p. 17)

— o Libertário aconselha o Estadista a tornar-se «dispensável» (p. 19)

- «o que veio Cristo fazer ao mundo», em oposição ao que fazem os partidários do Estado Novo (p. 22)

- a função do homem de autoridade (p. 22)

- critica da atitude materialista ética do Estadista perante os homens; avaliação da «civilização política» portuguesa (p. 24)

- o Libertário aconselha o Estadista a não divinizar o Estado; papel do Estado e dos ministros (pp. 25-27)

- a política agrícola dos governantes que se seguiram a Mouzinho da Silveira (p. 27)

- o interesse do Estado e o interesse do Povo (p. 27)

- o desprezo do Estadista pelos homens (p. 28)

- caracterização do Estado Novo do ponto de vista económico (p. 31)

- projecto cooperativista para a agricultura (p. 32)

- o papel do Estado e o papel do povo (p. 33)

- funções do Ministério da Cooperação; conselho ao Estadista (o mesmo que o da p. 19) (p. 33)

— modo como se desenvolverá o cooperativismo (p. 34)

- os pequenos e médios proprietários na Democracia Cooperativa (p. 35)

— conclusão do Diálogo Segundo; conselho ao Estadista (já referido) (p. 35)

- as granjas colectivas no plano de reforma agrária (p. 40)

— as «rendas excessivas» no Alentejo (p. 45)

- o ensino do crédito cooperativo aos colonos (p. 45)

- educação do povo para o governo económico (p. 46)

- a estrutura dos edifícios escolares (p. 49)

- conselho ao Estadista igual ao já referido (p. 50)

- um ditame de Cristo (p. 53)

- uma norma: «nunca mentir» (p. 56)

— o poder e o espírito (p. 57)

- exemplos de descobertas científicas (p. 59)

— objectivo da actuação dos «reformadores com alma» (p. 59)

- conselhos ao Estadista: «Pensa... em libertar os homens, o povo...» (p. 60)

- lema da Revolução Francesa (p. 82) 


\section{Antonio Sérgio}

B I B L I O G R A F I A

1. Obras de António Sérgio

SÉRGIO, António - Ensaios, l. $^{\mathrm{a}}$ ed., Lisboa, Sá da Costa, 8 vols. 1971-74.

* Antigona. Drama em três actos, Porto, Ed. da República, 1930.

* «Sobre a reforma do legislativo», Seara Nova, n. ${ }^{\circ}$ 293, 7-4-1932.

* «Um inquérito» (resposta a um inquérito aberto pelo 'Diário da Noite')», Seara Nova, n. ${ }^{\circ}$ 300, 26.5.1932.

* «A República e a religião», Seara Nova, n. ${ }^{\circ}$ 305, 30.6.1932.

* «O programa, a organização e a acção como fontes permanentes da concórdia», Seara Nova, n. $^{\circ} 323,3.11 .1932$.

* «Retalhos de Doutrina Democrática», Seara Nova, n..$^{\circ} 327$, 12.1.1933.

* «Mais retalhos», Seara Nova, $\mathbf{n} .^{\circ}$ 332, 2.3.1933.

* "Grupo 'Renovação Democrática'», Seara Nova, n. ${ }^{\circ} \quad 336$, 30.3.1933.

* «Diálogo de um democrata e de um estadista burguês», Seara Nova, n. 340, 27.4.1933.

* «Cooperativa e parlamento», Seara Nova, n. ${ }^{\circ}$ 344, 25.5.1933.

* Democracia. Diálogos de Doutrina Democrática. Alocução aos Socialistas. Cartas do Terceiro Homem. I. $^{a}$ ed., Lisboa, Sá da Costa, 1974.

* "A propósito dos dizeres de um jornalista», Seara Nova, n. ${ }^{\circ}$ 353, 31.8.1933.

* «Uma opinião sobre o falso corporativismo à fascista», Seara Nova, n. ${ }^{\circ}$ 357, 28.9.1933.

* «Sobre o Socialismo de Antero», Seara Nova, n. ${ }^{\circ}$ 362, 2.1.1933.

* «Em torno da 'Ilusão Revolucionária' de Antero», Seara Nova, n. ${ }^{\circ}$ 406-408, 11.9 .1934$.

* Um problema anteriano. Lisboa, Ed. do Autor s.d.

* Antero de Quental e António Vieira perante a civilização cristã dos seus próprios tempos. Porto, Biblioteca Fenianos, 1948.

* Cartas de Problemática, Lisboa, Ed. Inquérito, 1952-55.

* Antologia Sociológica. Pátio das Comédias, das Palestras e das Pregações., l.a ed., Lisboa, Sá da Costa, 1978.

2. Obras e artigos sobre António Sérgio ou com referências

BAPTISTA, Jacinto - Surgindo vem ao longe a nova aurora... Para a história do diário sindicalista «A Batalha» 1917-1927. Lisboa, Bertrand, 1977.

BARREIRA, Cecília - «O ideário seareiro. Alguns apontamentos para uma polémica (1921-1926)» Sondagens em torno da Cultura e das ideologias em Portugal (séc. $X I X-X X)$. Lisboa, Polemos, Col. Temas Portugueses, 1983 pp. 59-65.

GODINHO, Vitorino Magalhães - «António Sérgio: presença do passado, presença do futuro», Seara Nova, n..$^{\circ}$ 1507, Maio 1971, pp. 36-38. Para a Renovação da Política Nacional, Lisboa, Sá da Costa, Cadernos Livres, 1978.

GRÁCIO, Rui - «Pedagogia de acção social e racional de António Sérgio", Seara Nova, n. ${ }^{\circ} 1370$, Dez. 1959, pp. 389 e 398-399.

LOPES, Fernando Farelo - «A rendição da cultura liberal», Análise Social, $.^{\circ} 64,1980$, pp. 799-809. 
«O liberalismo decadente da Seara Nova (algumas hipóteses).» $O$ Fascismo em Portugal. Actas do Colóquio realizado na Fac. de Letras de Lisboa em Março de 1980, Regra do Jogo, 1982, pp. 141-165.

MATOS, A. Campos - Bibliografia de António Sérgio, Separata de Vértice, Coimbra, 1971.

SÁ, Victor de - Esboço Histórico das Ciências Sociais em Portugal, Lisboa, Secretaria de Estado da Cultura, Col. Biblioteca Breve, 1978.

SACRAMENTO, Mário - «Eis a critica, querido mestre e amigo» Diário de Lisboa, Suplemento Literário, 30.1.1969.

SERRÃO, Joel - «Nota sobre a importância do método no ensaismo de António Sérgio», Seara Nova, n. ${ }^{\circ} 1461$, Julho de 1967, pp. 205-206.

«Para uma caracterização do ensaismo de António Sérgio», O Tempo e o Modo, n. ${ }^{\circ}$ 47/48, Lisboa, Março/Abril, 1967, pp. 331-340.

«António Sérgio, o educador», O Tempo e o Modo, n. ${ }^{\circ}$ 69/70, Março de 1969, pp. 242-249.

«Para uma apologia de António Sérgio», Portugueses somos, Lisboa, Livros Horizonte, s.d., pp. 75-119.

VILHENA, Vasco Magalhães - António Sérgio e a Filosofia, Lisboa, ed. Cosmos, 1960 .

António Sérgio, o idealismo crítico e a crise da ideologia burguesa, Lisboa, Seara Nova, col. Argumentos, 1964.

«Em torno da génese do idealismo filosófico de António Sérgio» Homenagem a António Sérgio, Lisboa, Academia das Ciências de Lisboa, Instituto de Altos Estudos, 1976, pp. 123-145.

3. Obras sobre análise gramatical e análise de conteúdo

BARDIN, Laurence - Análise de Conteúdo, Lisboa, Edições 70, 1979.

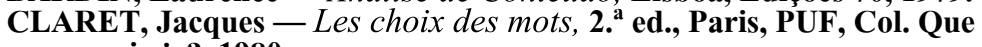
sais-je?, 1980.

LAPA, Manuel Rodrigues - Estilística da Língua Portuguesa, 10. ed., revista e actualizada, Coimbra, Coimbra ed., 1979.

MAINGUENEAU, D. - Initiation aux méthodes de Vanalyse du discours, Paris, Hachette Université, 1976.

MARQUES, F. Costa $-A$ análise literária, 3. ${ }^{\mathrm{a}}$ ed., Coimbra, Livraria Almedina, 1972.

ROBIN, Régine - Histoire et Linguistique, Paris, A. Colin, 1973.

4. Obras de carácter geral

CUESTA, Pilar Vasquez e LUZ, Maria Albertina M. da - Gramática da Língua Portuguesa, Lisboa, Edições 70, 1978.

CUIVILLIER, Armand - Vocabulário de Filosofia, Lisboa, Livros Horizonte, 1973.

CUNHA, Celso - Gramática do Português Contemporâneo, Belo Horizonte, Ed. Bernardo Álvares, 1978.

Dicionário de História de Portugal, dir. Joel Serrão, Lisboa, I. Editoriais, 4 vols. 1963-71.

Grande Enciclopédia Portuguesa e Brasileira, Lisboa/Rio de Janeiro, 40 vols. ed. Enciclopédia Lda., 1935-1960.

Le Langage, Les Encyclopédies du Savoir Moderne, dir. de Bernard Pottier, Paris, RETZ, 1973. 


\section{Antonio Sérgio}

LOPES, óscar - História Ilustrada das Grandes Literaturas. Literatura Portuguesa, II vol., Lisboa, Ed. Estúdios Cor, 1973, pp. 479$-488$.

MARQUES, A. H. de Oliveira - História de Portugal, 2. ${ }^{\mathrm{a}}$ ed., vol. III, Lisboa, Palas ed. 1981. 